\title{
Crowdfunding and bank financing: substitutes or complements?
}

\author{
Anton Miglo
}

Accepted: 4 October 2021

(C) The Author(s) 2022

\begin{abstract}
In this paper, we analyze a firm choice between crowdfunding and bank financing. For many entrepreneurs, it is an important issue. We analyze a model where the choice of financing is affected by moral hazard problem regarding the choice of production scale that favors bank financing, and by the uncertainty about market demand that favors crowdfunding. We argue that long crowdfunding campaigns or campaigns with large targets usually are less efficient in mitigating moral hazard problem than small/short campaigns. We also argue that high-quality firms and firms with potentially large markets will tend to select bank financing while projects with largest amount of investment should select mixed financing where the firm uses a short crowdfunding campaign and a bank loan. Most of our model empirical predictions have not been directly tested so far while they are indirectly consistent with available evidence.
\end{abstract}

Plain English Summary A financing strategy where crowdfunding and bank financing complement each other can be an optimal choice for entrepreneurs as compared to pure crowdfunding or pure bank loan strategy. In this paper we analyze a firm choice

A. Miglo $(\square)$

University of Salford (main), Salford, UK

e-mail: a.miglo@uea.ac.uk

A. Miglo

University of East Anglia, Norwich, UK between crowdfunding and bank financing. For many entrepreneurs it is an important issue. We argue that long crowdfunding campaigns or campaigns with large targets usually are less efficient in mitigating moral hazard problem than small/short campaigns. We also argue that high-quality firms and firms with potentially large markets will tend to select bank financing while projects with largest amount of investment should select mixed financing where the firm uses a short crowdfunding campaign and a bank loan. These findings should help entrepreneurs with selecting an optimal financing strategy. The government should limit the size of reward-based crowdfunding campaigns. This should increase the extent of its usage by entrepreneurs. It may be appropriate in current conditions given that the amount of bank loans by far exceeds that of crowdfunding.

Keywords Crowdfunding - Debt financing · Moral hazard · Reward-based crowdfunding · Demand uncertainty

JEL Classification D82 - G32 $\cdot$ L11 $\cdot$ L26 $\cdot$ M13

\section{Introduction}

Crowdfunding is the method of raising funds from a large number of investors usually performed online. It is sometimes credited as a top 10 invention of the $21 \mathrm{st}$ 
century. ${ }^{1}$ It offers a new way of financing as compared to traditional finance, e.g. bank loans or equity financing. Research on crowdfunding is quickly growing. Despite an immense amount of theoretical interest in crowdfunding, empirical evidence shows that in practice crowdfunding is still behind bank loans among, for example, small-medium-size enterprises (SMEs). ${ }^{2}$ In the absence of their own resources or funds from family and friends, bank loans are the most important source of external funds for these firms. It might seem surprising given that SMEs are supposed to have difficulties with obtaining bank loans because they lack experience, credit history, credit rating, assets (that can be used as collateral) etc. ${ }^{3}$

In this article, we analyze the firm choice between crowdfunding and debt financing. Our research question is motivated by the following. Firstly, as follows from previous paragraph, both bank loans and crowdfunding are important sources of financing for modern entrepreneurs and many businesses deal with this choice (see, e.g., Blaseg \& Koetter, 2016; Xu, 2018; Xu et al., 2020; Cole et al., 2019; Bernardino \& Santos, 2020). Although in some cases either a pecking order exists in a sense that entrepreneurs select crowdfunding because they were refused by a bank or a reverse pecking order where entrepreneurs select bank financing because of lack of knowledge about crowdfunding (Bernardino \& Santos, 2020), in many cases this choice is not so obvious. There are cases where entrepreneurs explain their choice of crowdfunding by their intention of learning market feedback ("wisdom of the crowd"); in some cases they had other choices including bank loan and in some cases entrepreneurs selected a mixed financing. ${ }^{4}$ Cole et al. (2019) argue that many entrepreneurs use bank financing to finance

\footnotetext{
$\overline{1^{1} \text { http://www2.technologyreview.com/tr10/?year=2012 }}$

${ }^{2}$ E.g., the total amount of bank loans outstanding is $168 \mathrm{bln}$ in the UK (Fig. A.1 in Small Business Finance report by British Business Bank 2019/20) and the volume of reward-based crowdfunding is about 6 bln. (based on https://p2pmarketdata. com/crowdfunding-statistics-worldwide/).

${ }^{3}$ See, e.g., Stiglitz and Weiss (1981), Jaffee and Russell (1976), Watson (1984), Bhattacharya and Thakor (1993), Parker (2002), Arnold and Riley (2009), and Su and Zhang (2014).

${ }^{4}$ See, e.g., the cases of Even Gori in https://www.entrepreneur. com/article/249069, Andrew Denham at https://socialmediaweek.org/blog/2012/02/crowdfunding-bicycle-building-aninterview-with-andrew-denham-of-the-bicycle-academy/, and start-up Mouse that we discuss later. See also Tamburro (2018) and Cole et al. (2019) etc.
}

some costs of their crowdfunding campaign and many of them use personal or business credit cards etc. Further debts can arise from not necessarily bank loans but, for example, from relationship with suppliers. ${ }^{5}$ Most businesses have these relationships so to some extent our results can be applied to these businesses as well. In the future one would expect that the problem of the choice between bank loan and crowdfunding will become even more important given reductions in the knowledge gap and also given that more sources of debt financing become available for entrepreneurs (e.g., FinTech loans). ${ }^{6}$

Secondly, in academic literature both bank financing and crowdfunding are often considered as indicators of entrepreneur's quality. There are four research directions related to this area. One is based on asymmetric information between firms and investors and argues that bank financing serves as a signal of firm's quality as compared to, for example, equity financing (see, e.g., Leland and Pyle, 1977; Ross, 1977). Different methods exist for high-quality firms to obtain bank loans including collateral (Bester, 1987) or other types of signals (e.g., Eddleston et al., 2016). In the spirit of this literature one would expect that when selecting between bank loans and equity-based crowdfunding good quality firms would select the former and vice versa. Note also that empirical evidence regarding signalling effect of debt vs. equity is mixed. ${ }^{7}$ The second line is related to credit rationing idea. It argues that firms operating in uncertain environments with imperfect information (e.g., SMEs, innovative firms, start-ups etc.) should have difficulties with obtaining bank loans due to market failure in an environment with asymmetric information or moral hazard problems (Stiglitz \& Weiss, 1981). Under this view all such firms (including good firms) should look for alternative finance. This implies that one should observe that borrowers with established business cycle without significant demand uncertainty will more likely use

\footnotetext{
${ }^{5}$ See, e.g., Tamburro (2018), Cole et al. (2019), Kohler et al. (2000), Cuñat and Garcia-Appendini (2012), and Yazdanfar and Öhman (2017).

${ }^{6}$ See, e.g., Azizaj (2020). Fenwick et al. (2017) mentioned supply chain financing related to fintech development.

${ }^{7}$ The empirical studies typically find a negative relation between profitability and leverage (Titman \& Wessels, 1988; Rajan \& Zingales, 1995; Fama \& French, 2002; Frank \& Goyal, 2009). Eckbo (1986) and Antweiler and Frank (2006) find insignificant changes in stock prices in response to straight corporate debt issues.
} 
bank loans while firms with high uncertainty may be interested in alternative finance. In the spirit of this literature Blaseg and Koetter (2016) find a substitution effect between equity-based crowdfunding and bank loans, i.e., firms working with distressed banks will more likely seek crowdfunding. Third line of literature argues that high-quality firms can use crowdfunding to signal their quality and further seek for traditional finance provided by banks or other large investors (Roma et al., 2017; Chen et al., 2018; Babich et al., 2019). Finally the fourth line suggests that rewardbased crowdfunding is an indicator of firm's quality. Mollick (2014) argues that high-quality entrepreneurs use reward-based crowdfunding to signal their quality in similar way they use other financing tools. In Miglo and Miglo (2019) high-quality firms use reward-based crowdfunding as a signal. ${ }^{8}$ In Fairchild et al. (2017) there is a non-monotonic relationship between firm's quality and its choice between crowdfunding and venture capital finance. ${ }^{9}$

Thirdly, both bank financing and reward-based crowdfunding are closely related to the choice of firm production scale. Reward-based crowdfunding is an innovative method of financing where investors/backers participating in financing also receive firm's product/services in most cases which is equivalent to product pre-sales (Belleflamme et al., 2014) that in turn directly affects the firm expected production scale. Debt financing literature also considers these links (Brander \& Lewis, 1986; Bolton \& Scharfstein, 1990; Williams, 1995; for a recent review see, for example, Li and Wang (2019) $)^{10}$ and argues that debt financing strongly affect the firm production decisions. For example, Brander and Lewis (1986) argue that product markets and financial markets have important linkages. They consider a model in which financial and output decisions follow in sequence and show that limited liability may commit a leveraged firm to a more aggressive output stance.

Fourth, our research question is related to one of the most important questions in finance namely the link

\footnotetext{
${ }^{8}$ Chod and Lyandres (2021) argue that initial coin offerings or ICO (similar to the spirit of reward-based crowdfunding because the firm sells tokens during ICO and the holders of tokens can use them to purchase firm products) can be used by high-quality entrepreneurs.

${ }^{9}$ See also Chakraborty and Swinney 2019.

${ }^{10} \mathrm{~A}$ recent example is Platt (2020) that studies interactions between product strategy and corporate bonds spreads.
}

between firm size and its choice of financing strategy. On the one hand a traditional corporate finance line of research (that is mostly based on the tradeoff theory of capital structure, see, e.g., Rajan and Zingales (1995), Frank and Goyal 2009) argues that firm's size is positively correlated with debt (as opposite to equity). In the spirit of this literature large firms should look for bank financing while small firms should look for alternative finance. On the other hand in entrepreneurial finance literature (regarding innovative firms, risky firms etc.) these linkages seem to be not straightforward. For example, there is no clear comparative static result about the link between firm size and its financing strategy in theoretical literature analyzing the choice between bank financing and venture capital (see, e.g., Landier, 2002; De Bettignies \& Brander, 2007; Winton \& Yerramilli, 2008). Also a recent wave of literature discovered significant interests in debt financing by small entrepreneurial firms (see, e.g., Ang, 1992; Berger \& Udell, 1998; Cole, 2010, 2013; Brav, 2009; Ang et al., 2010; Robb \& Robinson, 2012). Third we see examples of large firms that use crowdfunding. ${ }^{11}$

Finally, some authors have asked the question if crowdfunding and bank financing are substitutes or complements (see, e.g., De Buysere et al., 2012; Xu, 2018; Cole et al., 2019)? Cases where entrepreneurs use crowdfunding because they do not have access to bank loans (or where the cost of debt financing is too high) and the examples discussed in Blaseg and Koetter (2016) and Xu (2018) support the former. On the other hand cases where firms use mixed financing support the latter (see also Cole et al., 2019). A good example is startup Mous, the creator of innovative phone cases that keep headphones from getting tangled. It received a $\$ 7000$ loan from an investment company VirginStartUp to get start on creating their first phone cases. They also conducted a crowdfunding campaign on Kickstarter (largest crowdfunding platform) in order to expand, reaching their target to

\footnotetext{
${ }^{11}$ David Mandelbrot, CEO of Indiegogo, mentioned that large companies like Procter and Gamble, Honeywell and Bose use Indiegogo (the second-largest crowdfunding platform) to launch new products to an audience they can engage with directly. https://venturebeat.com/2018/01/15/ indiegogo-moves-beyond-crowdfunding-to-helpstartups-withmanufacturing/.
} 
raise over $\$ 12,000 .{ }^{12}$ Some legal researchers also recognize the importance of mixed financing where a firm simultaneously uses both crowdfunding and bank financing (see, e.g., Tamburro, 2018). A special report by crowdfundinder.co.uk suggests “...Using crowdfunding alongside traditional funding can add an additional layer of sustainability to projects. A number of funding bodies in our research said they'd like their projects to have diverse funding incomes to increase economic resilience. Crowdfunding is a new revenue stream with additional benefits that deliver greater sustainability." 13 Cases where firms use crowdfunding in order to later obtain bank loans (discussed previously) also represent an example where bank loans and crowdfunding are rather complements. An interesting example is crowdfunding platform Ulule that develops partnerships with different banks ${ }^{14}$ in order to provide innovative firms with opportunities to get a financing strategy that includes both crowdfunding and traditional bank loans. ${ }^{15}$ So our aim is to build a model that analyzes the entrepreneur's choice between crowdfunding and bank loan and that will be consistent with different outcomes of this choice discussed in this paragraph.

We build a model of entrepreneurial choice between bank financing and crowdfunding in order to contribute to questions discussed above. One of the model features is the connection between firm's financing and production scale choice as discussed in point 3 above. We consider a model where a firm has an investment project. The firm is owned by an entrepreneur and needs to raise funds to finance its project. The firm faces a moral hazard problem when making production decision and on the other hand it faces demand uncertainty. The firm may raise funds by using debt or crowdfunding ${ }^{16}$ or by using a mix of both. Financing stage is followed by production stage. If crowdfunding is used, firm receives a signal

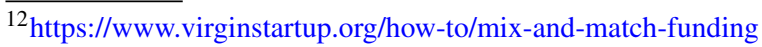
-options-launch-your-business

${ }^{13}$ https://www.crowdfunder.co.uk/uploads/biz_dev/special_ report_grants_loans_crowdfunding.pdf

${ }^{14}$ Including such banks as BNP Paribas. See, e.g., https:// lenderkit.com/blog/banks-and-crowdfunding/

${ }^{15}$ https://www.americanbanker.com/news/french-crowdfundingplatform-courts-bank-partners-to-gain-u-s-foothold

${ }^{16} \mathrm{We}$ focus on reward-based crowdfunding in the spirit of point 3 discussed above. We provide more discussions regarding other types of financing in Section 7.
}

about demand. After finishing its crowdfunding campaign, the firm can use spot sales. Bank financing is costly. It can include direct cost of preparing business plans and other documents, the time and effort spent on negotiating with banks etc. as well indirect costs such as bankruptcy/liquidation costs in case the firm fails and is not able to continue its operations. ${ }^{17}$ On the other hand, banks have greater capacity compared to most other capital providers, banks managers are able to lend large sums of money to firms if they find them financially attractive while with crowdfunding the amount of funds that can be raised during the campaign is limited (see, e.g., Bernardino and Santos, 2020; Hui et al., 2014; Durkin et al., 2016). This is because not all potential customers have access to internet; not all of them like to use internet for purchases; not of all of them are comfortable with financing innovations etc. So in the model we assume that the amount of funds that can be raised during the crowdfunding campaign is limited. By introducing the market limitations for crowdfunding and by analyzing different scenarios depending on the size of these limits the model helps us generate predictions about the implications of internet development on crowdfunding and firm's financing strategies that may take place over time.

Some intuitions are as follows. In a perfect market without moral hazard and demand uncertainty financing choice is irrelevant. When demand is known but the firm faces a moral hazard problem, bank financing dominates crowdfunding since it better stimulates the entrepreneur in choosing a socially optimal production decision. With crowdfunding, the firm faces a pre-commitment problem (due to the nature of crowdfunding when many items are "pre-sold" during crowdfunding campaign). This creates a distortion in optimal choice during production stage. When moral hazard is combined with demand uncertainty, the trade-offs result in different outcomes. First we show that if the market limitations are soft, i.e., market limitations are not significant for the firm, crowdfunding may not be feasible due to moral hazard problems related to production scale choice during spot sales that in turn leads to low prices during spot sales and disincentivizes potential backers from participating in crowdfunding campaign due to no-arbitrage condition violation. An implication of this result is that

\footnotetext{
${ }^{17}$ The costs related to crowdfunding are usually smaller as compared to bank financing. We discuss these costs and their implications for the model in Section 4.4.
} 
even if over time market limitations for crowdfunding disappear the problem of moral hazard related to production choice would still take place for crowdfunding. Second when crowdfunding is feasible the trade-off between bank financing and crowdfunding depends on interplay of bankruptcy cost, investment size, the type of crowdfunding, the type of signal received etc. For example we find that mixed financing may be optimal when crowdfunding market is quite limited but at the same time the investment size is relatively large. In this case pure crowdfunding may not deliver sufficient funds to cover investment costs while pure bank financing may imply large investment losses when demand is low. We also find that firms would usually prefer short campaigns to long campaigns since they have more chances to be feasible and overcome the moral hazard problem related to production scale choice. Also we find that for a given amount of investment a firm of higher quality/or larger market size will look for a bank loan.

The rest of the paper is organized as follows. Section 2 provides a review of related literature. Section 3 presents the model description and some preliminary results. Section 4 analyzes the main case with moral hazard and demand uncertainty. Section 5 analyzes the role of campaign threshold in mitigating moral hazard issues. It also considers different types of signals. Section 6 presents the model's implications and its consistency with empirical evidence. Section 7 discusses the model's robustness and extensions and Section 8 concludes.

\section{Literature review}

Existing theoretical literature considering both crowdfunding and bank financing includes the following. Babich et al. (2019) study an optimal financing strategy for a start-up that uses crowdfunding that can follow by venture capital and/or bank financing. They model a bargaining game, with a moral hazard problem between an entrepreneur and a bank, and a double-sided moral hazard problem between the entrepreneur and a venture capitalist (VC), with respect to their non-contractible efforts. When designing crowdfunding campaign the entrepreneur should take into account the after-campaign consequences including opportunities to get $\mathrm{VC}$ or bank financing. In some cases crowdfunding can harm the entrepreneur and the VC because it can worsen VC moral hazard problems. Xu et al. (2020) investigate a firm's choice between crowdfunding and bank financing with both market uncertainty and wordof-mouth (WoM) communication. They find that the firm would adopt intertemporal pricing under crowdfunding, where the exact format is determined by the WoM and market uncertainty; under bank financing, however, the firm should always charge a fixed price invariant to those parameters. Miglo and Miglo (2019) mention bankruptcy cost in their model and compared crowdfunding with bank financing. If a firm takes a bank loan and it is not able to pay back its debt then the firm is bankrupt and there are bankruptcy costs involved. On the other hand, banks have a better ability to monitor and control entrepreneurs (as, for example, in Diamond, 1984). So optimal financing strategies should trade-off these factors. However, a mixed financing when the firm uses crowdfunding and debt financing simultaneously has not been analyzed in these articles. In addition we analyze the role of different types of crowdfunding campaigns and the role of different types of signals the firm receives about market demand when conducting a crowdfunding campaign.

Our paper is also related to the literature that analyzes crowdfunding role in learning market demand. Strausz (2017) argues that under demand uncertainty, crowdfunding improves screening for valuable projects. Entrepreneurial moral hazard threatens this benefit. Crowdfunding's after-markets enable consumers to actively implement deferred payments and thereby manage moral hazard. Chemla and Tinn (2019) develop a model where reward-based crowdfunding helps entrepreneurs obtain reliable feedback on their ideas early in their production cycle. Crowdfunding allows firms to learn about the total demand from a limited sample of target consumers preordering a new product. It creates a valuable real option as firms invest only if the estimated demand is sufficiently high. Miglo (2020a) studies the role of learning using crowdfunding in a competitive environment. The opportunity to observe both the funders' demand and the strategies of their competitors during the pre-sale stage helps firms improve their spot sale pricing and production decisions even if the pre-sale stage is costly (firms pay rewards to funders participating in the pre-sale stage). Schwienbacher (2018) analyzes risks related to crowdfunding campaigns. 
One of them relates to market demand. Reward-based crowdfunding offers a signal about the overall market potential of the entrepreneur's product. Raising money from professional investors does not offer the same informational feedback, since their decisions are mostly based on the assessment of the overall profitability of the investment opportunity and not on consumption. Miglo (2020b) analyzes the role of learning in a model of the choice between the different types of crowdfunding, which contains elements of the asymmetric information approach and behavioral finance (overconfident entrepreneurs). The paper finds that equity-based crowdfunding is a more efficient tool of learning the market wisdom for an entrepreneur that is consistent with Arkrot et al. (2017). None of these papers analyzes the role of learning through crowdfunding when it is used jointly with bank financing. We argue that it is an important relationship because learning information about market demand creates a good opportunity for bankers and entrepreneurs to reduce the cost of potential financial distress associated with bank financing. Also as was mentioned previously we also analyze different types of signals about market demand. In particular in above literature usually it is assumed that the signal is received at the end of campaign. In this paper we consider different cases regarding the nature of signal: we study the role of early signals, entrepreneurs choice between continuing and stopping the campaign or switching to spot sales after early signal is received, the role of campaign threshold etc.

\section{Basic model}

\subsection{Model description}

We consider a firm that owns an investment project. The project requires an amount of investment $I .{ }^{18}$ The variable cost of production is $c$ per item. The production is denoted by $q . p$ is the product price. The demand for the product is $q=a-p$ with probability 50\% (good or high demand scenario) and $q \equiv 0$ (bad or low demand scenario) otherwise, $a>c>0 .{ }^{19}$ The firm belongs to the shareholders who we will

\footnotetext{
${ }^{18}$ Section 7 discusses the model extensions and robustness with regard to different assumptions.

${ }^{19} q=a-p$ implies that $p \leq a$. So if $a<c$ then $p<c$ that makes the project "uninteresting" (unprofitable).
}

call the entrepreneur. The entrepreneur is responsible for selecting financing strategy/capital structure decisions and production/pricing decisions. To finance the project, the firm can either use a bank loan or crowdfunding. If the firm uses bank financing and is not able to pay its debts, it is liquidated that implies liquidation/bankruptcy costs $L .{ }^{20}$ If crowdfunding is chosen, the firm announces the crowdfunding (pre-sale) price $p_{c}$. Opportunities to raise funds using crowdfunding are limited. Let $\bar{q}$ be the maximal amount of orders that can be collected during crowdfunding. It does not create any problems for the firm if $\bar{q}$ is sufficiently high, i.e., if $a-p_{c} \leq \bar{q}$. However if $a-p_{c}>\bar{q}$, the number of pre-orders during crowdfunding $q_{c}$ will be equal to $\bar{q}$ and not $a-p_{c}$. The advantage of crowdfunding though is that the firm receives a signal about product demand. More specifically we assume that the firm can observe the number of pre-orders from backers $q_{c}$ and by observing $q_{c}$, the firm can see if $q_{c}$ is greater than 0 and realize if the demand is $q=a-p$ or $q \equiv 0 .{ }^{21}$ The remaining demand for the product $q^{\prime}$ is still driven by the same rule, i.e.,

$p=a-q_{c}-q^{\prime}$

The firm can sell products on the spot market. In fact if the firm financing is debt then all products will be sold on the spot market. If the firm uses crowdfunding then "sales" $q_{c}$ will be done via crowdfunding (i.e., in the form of pre-sale; the price $p_{c}$ ) and some sales $q_{s}$ will be done on the spot market (price $p_{s}$ ). Equation (1) implies that $p_{s}=a-q_{s}-q_{c}$. In general $p_{s}$ may not necessarily be equal to $p_{c}$. Consistent with the spirit of existing literature we assume that backers can anticipate differences in prices rationally (non-arbitrage condition) so a situation with $p_{s}<p_{c}$ cannot be an equilibrium (we provide more discussion later).

After finishing the crowdfunding campaign and receiving information about demand, the firm can withdraw from the project. In this case, the claimholders receive the value of funds raised during the campaign. We assume that the firm should make an investment $I$ before selling products on the spot market. Otherwise, the project fails.

\footnotetext{
${ }^{20}$ Further in Section 4.4 we will analyze the role of additional costs associated with bank loans and crowdfunding.

${ }^{21}$ Theoretically, if $p=a$ then under any scenario $q=0$ so the firm receives no information. However as will be shown, $p=a$ is never a part of equilibrium.
} 
Also we assume that:

$\frac{(a-c)^{2}}{4}-I>0$

Equation (2) implies that the project has positive net-present-value (NPV; calculations will be explained later) if the demand is known to be high.

When choosing its financing strategy, the firm faces a trade-off between the information about demand, cost of bank financing, limits to crowdfunding volume and moral hazard problems related to termination/continuation/production decisions. Everybody is risk-neutral and the risk-free interest rate is zero. The timing of events is present in Fig. 1.

\subsection{Perfect market}

Let us first consider a perfect market case when no moral hazard problem exists (i.e., the entrepreneur's choice of production is contractible) and the demand for the product is known and equals $q=a-p, a>0$ (if $q \equiv 0$, the firm will not undertake the project). Also $\bar{q}=\infty$ and $L=0$.

Lemma 1 In a perfect market, firms financing strategy is irrelevant and firm's value equals $\frac{(a-c)^{2}}{4}-I$.

Proof First note that since the demand is known no signal is received. No liquidation/project termination decision can take place neither (in a perfect market if the parties anticipate a non-profitable project it will not be undertaken).
The first-best production decision maximizes the firm total surplus: $q(a-q-c)-I$. So optimal

$q^{*}=\frac{a-c}{2}$

and the corresponding price is:

$p^{*}=a-q^{*}=\frac{a+c}{2}$

Consider bank financing. Let $F$ be the face value of debt (including principal and interest). The creditors total expected payoff should be equal $I$. Since the demand is known and the project has a positive NPV

$F=I$

Throughout the article, we do not model the specific types of financing for variable costs. The firm can arrange short-term financing including a bank loan to cover these costs as long as the production stage has a positive value overall. As was previously mentioned fixed costs must be paid before the production starts. There is no similar requirement for variable costs. Since $a>c$, as soon as the firm made investment $I$ the production can go ahead. There are many interpretations of this scenario (workers are paid at the end of the month after the products are sold, suppliers provide a trade credit for the firm, firm uses cash from previously sold products to pay for the production of current products etc.). This greatly shortens the calculations and simplifies the presentation. In fact in most cases the explicit modelling of loans that cover variable costs lead to the same result (we provide some examples below). The entrepreneur's profit equals earnings from sales minus costs including production costs and investment costs and minus interest

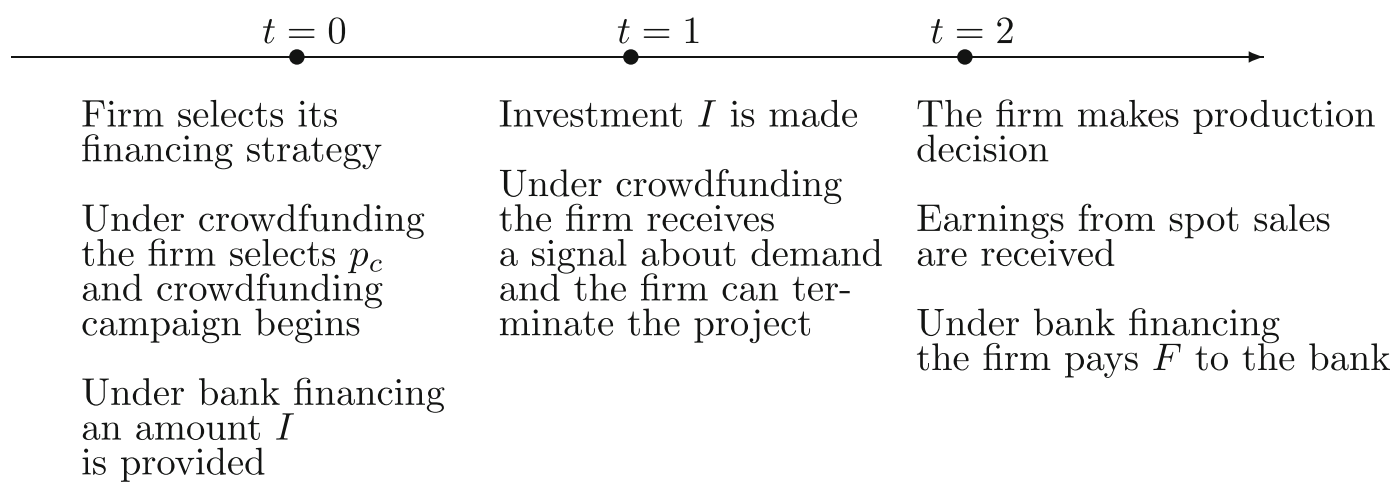

Fig. 1 The sequence of events 
( $R=F-I$ that is equal zero in a perfect market as implied by (4)) on debt: 22

$q(a-q-c)-I=\frac{(a-c)^{2}}{4}-I$

Now consider financing with crowdfunding. Optimal $q=\frac{a-c}{2}$ and optimal $p=p_{c}=\frac{a+c}{2}$. So $q_{c}=a-p_{c}=\frac{a-c}{2}$ and therefore optimal $q_{s}=$ $q-q_{c}=\frac{a-c}{2}-q_{c}=0$. In this case $p_{c}\left(a-p_{c}\right) \geq I$ (this condition assures that the funds received during crowdfunding campaign will cover the investment cost I). ${ }^{23}$ The firm's total profit equals the amount of sales (pre-sales) received minus investment costs and minus variable costs of production):

$p_{c} q_{c}-c q_{c}-I=\frac{(a-c)^{2}}{4}-I$

Lemma 1 is intuitive. In a perfect market when demand is known, parties do not update their information. If the project is unprofitable it will not be started. The choice of financing strategy is irrelevant (Modigliani and Miller, 1958).

\subsection{Moral hazard}

Let us now consider the case when the entrepreneur is subject to moral hazard, i.e., production decision by the entrepreneur is non-contractible. As in previous section, the demand for the product is known and equals $q=a-p, a>0$. Also as in previous section, $\bar{q}=\infty$ and $L=0$.

\footnotetext{
${ }^{22}$ For the case when the firm takes a loan to finance its variable costs, the detailed description of cash flows is provided below. Initially the firm receives an amount of cash $D=I$, then pays $I$ for investment costs. Then the firm can arrange a second loan $D_{2}=c q$ with a face value $F_{2}=D_{2}$. This cash will be used to pay for the variable costs. Neither of these values enters the firm's objective function. The firm' final amount of cash (that is to the firm profit in the absence of taxes) equals the value of sales minus the face value of first debt and minus the face value of second debt or $q(a-q)-F-F_{2}=q(a-q-c)-I$ that is identical to the main text.

${ }^{23}$ If $p_{c}\left(a-p_{c}\right)$ is strictly greater than $I$, the firm will invest $I$ and the rest will be counted as sales (see, e.g., Gabison, 2015; see also https://www.weblaw.co.uk/ebooks/ crowdfunding-guide.pdf). In Section 5 more discussions about possible scenarios in this case are provided that consider different types of crowdfunding campaigns, the role of the campaign threshold etc.
}

Proposition 1 In a market with moral hazard when the demand is known firms select bank financing and the firm's value equals $\frac{(a-c)^{2}}{4}-I$.

Proof First note that since the demand is known no signal is received. No liquidation can take place neither. Consider bank financing. The difference with the perfect market case is that there is a moral hazard problem with regard to the choice of $q$ by entrepreneur so the contracts should be incentivecompatible. First consider the firm production decision. The entrepreneur chooses $q$ to maximize

$q(a-q-c)-I-R$

(when the demand is known, the parties can correctly anticipate the decision by the firm and since there is no risk the interest equals zero). So optimal $q$ that maximizes (5) equals $q=\frac{a-c}{2}$. Now consider initial financing. The creditors total expected payoff should be equal $I$. The following contract is optimal: $F=I$. In this case the entrepreneur selects $q=\frac{a-c}{2}$, the firm's sales minus costs equal $q(a-q-c)=\frac{(a-c)^{2}}{4}$. This is greater than $I$ by (2) so the firm will be able to pay the face value of debt back to the bank. The entrepreneur's profit equals $\frac{(a-c)^{2}}{4}-I$.

Under crowdfunding that we consider next, firm collects cash for products before making production decision so this distorts the decision-maker's incentives in the production stage because a part of revenue from sales was collected prior to production decision and this part does not enter the firm objective function when production decision is made. This problem does not exist with bank financing where products are sold on the spot market. The disadvantage of bank financing is that it does not provide information about market demand that we consider in Section 4.

Consider the production decision under crowdfunding. Let $C$ be the amount of funds raised by crowdfunding: $C=p_{c} q_{c}$. The entrepreneur chooses $q_{s}$ to maximize $q_{s}\left(a-q_{s}-q_{c}-c\right)+\Pi_{1}$ where $\Pi_{1}$ is the firm profit if it decides to not sell any items on the spot market, i.e., when $q_{s}=0$. We have $\Pi_{1}=C-I-c q_{c}$. Two cases are possible. $1 . a-c \geq q_{c}$. Then optimal

$q_{s}^{*}=\frac{a-q_{c}-c}{2}$

and the firm profit equals

$\frac{\left(a-q_{c}-c\right)^{2}}{4}+\Pi_{1}$ 
2. $a-c<q_{c}$. Optimal $q_{s}=0$ and the firm profit equals $\Pi_{1}$.

Since the first-best outcome is achievable with bank financing as was shown previously we only need to see if it is possible with crowdfunding. Otherwise, bank financing will be used. In a first-best scenario $p_{c}=$ $\frac{a+c}{2}$ and respectively $q_{c}=\frac{a-c}{2}$. Then as follows from (1) $p_{s}=a-q_{s}-q_{c}=a-q_{s}-\frac{a-c}{2}$. This should be equal $\frac{a+c}{2}$ that is only possible if $q_{s}=0$. However it is never the case. As follows from above $q_{s}=0$ only if $a-q_{c}-c<0$ that is not the case because $a-q_{c}-c=\frac{a-c}{2}>0$. So $q_{s}>0$ and then $p_{s}=$ $a-q_{s}-\frac{a-c}{2}=\frac{a+c}{2}-q_{s}<p_{c}$. This implies that crowdfunding campaign with $p_{c}=\frac{a+c}{2}$ fails by noarbitrage argument.

This result holds for most parts of this article and is robust to different assumptions, e.g., if one introduces a mixed financing (Section 4.4), different types of crowdfunding campaigns or different signals about demand (Section 5), positive demand in a bad scenario (Section 7.1), or a discount for crowdfunding participants (in the spirit of Miglo 2020a) that are related to waiting costs. In the latter case, for example, any item sold during crowdfunding costs the firm an amount $\beta$ as compared to spot sales, so the net price for backers is $p_{c}-\beta$. However the no-arbitrage condition is still $p_{c} \leq p_{s}$ that does not hold as was shown above. $\beta$ is irrelevant since it is not a gift in economic sense but a cover for the waiting costs. To summarize, we can see that in general under crowdfunding the firm collects cash for products before making production decision so this distorts the incentives in production stage. This problem does not exist with bank financing where products are sold on the spot market. The disadvantage of bank financing is that it does not provide information about market demand that we consider next.

\section{Main case: moral hazard and uncertain demand}

Let us now consider the main case when the demand for the product is unknown and the entrepreneur's production decision is not contractible. Also $\bar{q}<\infty^{24}$

\footnotetext{
${ }^{24}$ As will be shown in fact the crucial condition is $\bar{q}<a$. Otherwise, the effect of $\bar{q}$ on the outcome of crowdfunding campaign is identical to the case $\bar{q}=\infty$.
}

and $L \geq 0$. It has two implications. Firstly, the amount of funds raised by crowdfunding will be limited as explained in the model description. Secondly, there are liquidation/bankruptcy costs if the firm is not able to pay its debt. There are different ways of modelling these costs. For simplicity we suppose that when the firm is not able to pay its debt (usually it happens when the demand is low) there is cost $L$. Technically we model it as a cost that is paid by the financial institution. In reality the modelling of this part would depend on the bankruptcy system in each country (see, e.g., Senbet \& Seward, 1995; Hotchkiss et al., 2008; Senbet $\&$ Wang, 2012). Note though that this assumption is not crucial. The bank will anticipate bankruptcy costs arising in the negative scenario so the face value of the loan will take it into account (see, e.g., Weston, 1977; Leland, 1994; Leland \& Toft, 1996). Alternatively $L$ may be modelled as the value of lost business opportunities when the firm is liquidated. Although it would change the calculations, the main intuitions would not be affected.

\subsection{Bank financing}

Consider first bank financing. Debt can be risky, i.e., $F$ is not necessarily equal $I$. Since the demand is unknown, the amount of earnings in some cases may not be sufficient to cover debt. In this case the entrepreneur makes no profit. We start the solution by working backwards.

\subsubsection{Production decision}

First consider the production decision. In the case of bank financing, the demand is unknown. The entrepreneur chooses $q$ to maximize

$$
E \max \{0, q(a-q-c)-I-R\}=0.5(q(a-q-c)-I-R)
$$

This means that the demand is high with probability $50 \%$ and otherwise, the entrepreneur's profit is zero. Optimal $q^{*}=\frac{a-c}{2}$ and the firm expected profit equals:

$0.5\left(\frac{(a-c)^{2}}{4}-I-R\right)$ 


\subsubsection{Initial financing}

Initially, the creditors expected payoff should be equal to $D$. Two cases are possible. 1 .

$\frac{(a-c)^{2}}{8} \geq I+0.5 L$

This condition guarantees that $q^{*}$ is feasible, and the firm is able to pay its debt in the good scenario as will be explained below. Indeed if this is the case then we should have

$I=0.5 F-0.5 L$

It means that with probability $50 \%$, i.e., when $q=$ $a-p$, the creditors are paid in full $(F)$ and with probability $50 \%$ they receive nothing (this is because the price of the firm product is zero (i.e., the demand is absent) in low demand scenario) from the firm and there is a bankruptcy cost $L$.

Equation (11) implies that $F=2 I+L$ and $R=$ $F-I=I+L$. The entrepreneur's profit equals:

$$
\begin{aligned}
& 0.5\left(\frac{a-c}{2}\left(a-\frac{a-c}{2}-c\right)-2 I-L\right) \\
& =\frac{(a-c)^{2}}{8}-I-0.5 L
\end{aligned}
$$

Equation (10) implies that this is positive which means that the firm will be able to return the face value of debt to the bank so the bank will be interested in providing the loan.

2. $\frac{(a-c)^{2}}{8}<I+0.5 L$, then the bank financing is not feasible.

This leads to the following proposition.

Proposition 2 Under bank financing: (1) if $\frac{(a-c)^{2}}{8} \geq$ $I+0.5 L, F=2 I+L$ and the entrepreneur's profit equals: $\frac{(a-c)^{2}}{8}-I-0.5 L$; (2) if $\frac{(a-c)^{2}}{8}<I+0.5 L$ , bank financing is not feasible and the entrepreneur's profit is zero.

Proof Follows from above.

\subsection{Crowdfunding}

\subsubsection{Production decision}

The firm reaches this stage when the crowdfunding campaign is completed and the decision was made to not stop the project. Also at this stage the demand is known. Production stage can only be reached in a "good" scenario, i.e., one with a positive demand. Therefore the production decision follows same rules as described in Section 3.3.

\subsubsection{Continuation/liquidation decision}

Consider firm decision after the campaign is completed and the signal is received. The entrepreneur has 2 options: project termination or continuation. If the firm learned that $a=0$, the project will be terminated because the entrepreneur's profit cannot be positive. Consider a good case with positive demand. Two scenarios are possible.

1. $C>I$. Then if the project is terminated, backers get $C-I$ and the entrepreneur gets 0 . If the firm continues, then the entrepreneur's profit is given by (7). If it is greater than 0 , the entrepreneur will decide to continue.

2. $C<I$. Then the firm cannot continue. So the project is terminated and the entrepreneur's profit is 0 . In fact in this case, no one will invest in crowdfunding and the campaign fails.

\subsubsection{Initial financing}

Initially the firm sets the price $p_{c}$ to maximize the entrepreneur's expected profit П. Two scenarios are possible depending on expected decision at production stage. If the entrepreneur anticipates $q_{s}>0$ then initially he maximizes $\Pi=$ $0.5\left(\frac{\left(a-q_{c}-c\right)^{2}}{4}+p_{c} q_{c}-I-c q_{c}\right)$ subject to $p_{c} q_{c} \geq$ $I$, no-arbitrage condition

$p_{s}=a-q_{s}-q_{c}=\frac{a-q_{c}+c}{2} \geq p_{c}$

and also $a-c \geq q_{c}$ and $p_{s}<a$ (the last condition can be rewritten as $0 \leq a+q_{c}+c$ that holds). If the entrepreneur expects $q_{s}=0$, then he maximizes $\Pi=$ $0.5\left(p_{c} q_{c}-I-c q_{c}\right)$ subject to $p_{c} q_{c} \geq I, a-c<q_{c}$ and $p_{s}<a$.

Two cases are possible. 1. $p_{c} \geq a-\bar{q}$. This implies $a-p_{c} \leq \bar{q}$ and $q_{c}=a-p_{c}$. Then $p_{s}=a-q_{s}-q_{c}=$ $\frac{a-q_{c}+c}{2}=\frac{p_{c}+c}{2}$ and the no-arbitrage condition (13) can be written as $\frac{p_{c}+c}{2} \geq p_{c}$ or $p_{c} \leq c$ that does not hold because in this case the firm will not create any profit. This means that if $\bar{q}$ is sufficiently large 
(i.e., $\bar{q} \geq a-p_{c}$ ), the crowdfunding campaign is not feasible due to moral hazard problems translated into a violation of no-arbitrage condition that will be rationally anticipated by potential backers.

2.

$$
p_{c}<a-\bar{q}
$$

This implies $a-p_{c}>\bar{q}$ and $q_{c}=\bar{q}$. Then $p_{s}=$ $\frac{a-\bar{q}+c}{2}$ and the no-arbitrage condition (13) can be written as

$\frac{a-\bar{q}+c}{2} \geq p_{c}$

Comparing (14) and (15) we see that two situations are possible. (a) $a-\bar{q}>\frac{a-\bar{q}+c}{2}$ or $a-c>\bar{q}$. Then according to (6) the firm expects $q_{s}>0$ and hence it maximizes $0.5\left(\frac{\left(a-q_{c}-c\right)^{2}}{4}+p_{c} q_{c}-c q_{c}-I\right)=$ $0.5\left(\frac{(a-\bar{q}-c)^{2}}{4}+p_{c} \bar{q}-c \bar{q}-I\right)$ subject to (15) and $p_{c} \bar{q} \geq I$. If $\frac{(a-\bar{q}+c) \bar{q}}{2} \geq I$ the solution is

$p_{c}^{\prime}=\frac{a-\bar{q}+c}{2}$

If $\frac{(a-\bar{q}+c) \bar{q}}{2}<I$ this strategy does not work.

If $\frac{(a-\bar{q}+c) \bar{q}}{2} \geq I$ then initially the firm sets $p_{c}=$ $\frac{a-\bar{q}+c}{2}$. When the signal is good, $a-p_{c}>\bar{q}$ so $q_{c}=\bar{q}$ and the firm continues. $p_{s}=a-q_{s}-q_{c}=\frac{a-\bar{q}+c}{2}=$ $p_{c}, q_{s}=\frac{a-\bar{q}-c}{2}$ (note that in this case also $p_{c} \bar{q}=$ $\left.\frac{(a-\bar{q}+c) \bar{q}}{2}>I\right)$. The firm's expected profit equals:

$0.5\left(\frac{\left(a-q_{c}-c\right)^{2}}{4}+p_{c} q_{c}-c q_{c}-I\right)$

$=\frac{(a-\bar{q}-c)^{2}}{8}+\frac{(a-\bar{q}-c) \bar{q}}{4}-0.5 I$

(b) $a-\bar{q} \leq \frac{a-\bar{q}+c}{2}$ or $a-c \leq \bar{q}$. Then according to Section 3.3 the firm expects $q_{s}=0$ and hence it maximizes $0.5\left(p_{c} q_{c}-c q_{c}-I\right)=0.5\left(p_{c} \bar{q}-c \bar{q}-I\right)$ subject to (14) and $p_{c} \bar{q} \geq I$. Then if $(a-\bar{q}) \bar{q} \geq I$ the solution is

$p_{c}^{\prime}=a-\bar{q}$

This does not work because $a-c<\bar{q}$ implies $p_{c}<$ $c$ and the firm does not make any profit. If $(a-\bar{q}) \bar{q}<$ $I$, it does not work neither because the crowdfunding campaign fails to cover investment needs. This leads to the following proposition.

Proposition 3 Under crowdfunding: (1) if $\frac{(a-\bar{q}+c) \bar{q}}{2} \geq I$ and $a-c \geq \bar{q}$ then $p_{c}=\frac{a-\bar{q}+c}{2}$ and the entrepreneur's profit equals: $\frac{(a-\bar{q}-c)(a+\bar{q}-c)}{8}-0.5 I$; (2) if $\frac{(a-\bar{q}+c) \bar{q}}{2}<I$ or $a-c<\bar{q}$, crowdfunding is not feasible and the entrepreneur's profit is 0 .

Proof Follows from above.

\subsection{Choice of financing}

Finally compare the outcomes under each strategy.

Proposition 4 Consider a market with moral hazard and uncertain demand. If $L \leq \frac{(a-c)^{2}}{4}-(a-\bar{q}+c) \bar{q}$ then: (1) if $a-c>\bar{q}, \frac{(a-\bar{q}+c) \bar{q}}{2}>I$ and $\bar{q}>$ $2 \sqrt{I+L}$, the firm selects bank financing; if $a-c>\bar{q}$ and $\frac{(a-\bar{q}+c) \bar{q}}{2}>I$ and $\bar{q}<2 \sqrt{I+L}$, the firm selects crowdfunding; if $a-c>\bar{q}$ and $\frac{(a-\bar{q}+c) \bar{q}}{2}<$ $I<\frac{(a-c)^{2}}{8}-0.5 L$, the firm selects bank financing; if $a-c>\bar{q}$ and $\frac{(a-c)^{2}}{8}-0.5 L<I$ the project will not be undertaken; (2) if $a-c<\bar{q}$ and $I<\frac{(a-c)^{2}}{8}-0.5 L$, the firm selects bank financing; if $a-c<\bar{q}$ and $\frac{(a-c)^{2}}{8}-0.5 L<I$, the project will not be undertaken. If $L>\frac{(a-c)^{2}}{4}-(a-\bar{q}+c) \bar{q}$ then: (1) if $a-c>\bar{q}$, $\frac{(a-c)^{2}}{8}-0.5 L>I$ and $\bar{q}>2 \sqrt{I+L}$, the firm selects bank financing; if $a-c>\bar{q}, \frac{(a-c)^{2}}{8}-0.5 L>I$ and $\bar{q}<2 \sqrt{I+L}$, the firm selects crowdfunding; if $a-c>\bar{q}$ and $\frac{(a-\bar{q}+c) \bar{q}}{2}>I>\frac{(a-c)^{2}}{8}-0.5 L$, the firm selects crowdfunding; if $a-c>\bar{q}$ and $\frac{(a-\bar{q}+c) \bar{q}}{2}<I$, the project will not be undertaken; (2) if $a-c<\bar{q}$ and $I<\frac{(a-c)^{2}}{8}-0.5 L$, the firm selects bank financing; if $a-c<\bar{q}$ and $\frac{(a-c)^{2}}{8}-0.5 L<I$, the project will not be undertaken.

Proof Follows directly from Propositions 2 and 3 by comparing firm's values in different scenarios. For example consider the case:

$a-c>\bar{q}$

$\frac{(a-\bar{q}+c) \bar{q}}{2}>I$

The interpretation of these conditions is that if they both hold, crowdfunding is feasible: (17) implies that no-arbitrage condition holds and (18) implies that the 
amount of funds raised during the campaign covers the required amount of investments. If $L \leq \frac{(a-c)^{2}}{4}-(a-$ $\bar{q}+c) \bar{q}$ and respectively $\frac{(a-\bar{q}+c) \bar{q}}{2}<\frac{(a-c)^{2}}{8}-0.5 L$ that implies that $I<\frac{(a-\bar{q}+c) \bar{q}}{2}<\frac{(a-c)^{2}}{8}-0.5 L$, then if the firm uses bank financing, the entrepreneur's profit equals $\frac{(a-c)^{2}}{8}-I-0.5 L$ as follows from Proposition 2 . If the firm uses crowdfunding the entrepreneur's payoff equals $\frac{(a-\bar{q}-c)(a+\bar{q}-c)}{8}-0.5 I$ as follows from Proposition 3. The comparison of these values implies that bank financing will be chosen if and only if the following holds:

$\bar{q}>2 \sqrt{I+L}$

Figure 2 presents a graphical illustration of the above conditions for $a=1, c=0.1$ and $L=0.06$ (horizontal axes is $I$, vertical axes is $\bar{q}$ ).

Crowdfunding is optimal in the area between bold line (condition (19)), solid line (condition (18)), and diamond line (condition (16)). To the north of dash line (i.e., when $\bar{q}$ is large: $\bar{q}>0.9$ ), crowdfunding is not feasible because of moral hazard issues. No strategy works when investment is too large. To the right of box line (condition (10)), bank financing does not work and to the right of solid line crowdfunding does not work.

The effect of $\bar{q}$ is non-linear in a sense that on the one hand it should not be very large (as mentioned before because of moral hazard problems) and not too small (intuitively crowdfunding is not feasible in this case because of market limitations). For example, when $I$ is close to 0.05 there is an area under solid line where crowdfunding is not feasible and bank financing is optimal.

\subsection{Mixed financing}

Here we assume that to finance the project, the firm can either use a bank loan (Strategy 1), crowdfunding (Strategy 2) or a mix of both (Strategy 3). If Strategy 3 is used the firm receives an amount $D, D \leq I$ from a bank that is not necessarily equal $I$. In our basic model firms to some extent used mixed financing when selecting crowdfunding since by assumption they can arrange a bank loan to finance variable costs after completing the main campaign. It could be interpreted as a sequential mixed financing. In this section we consider simultaneous mixed financing when the

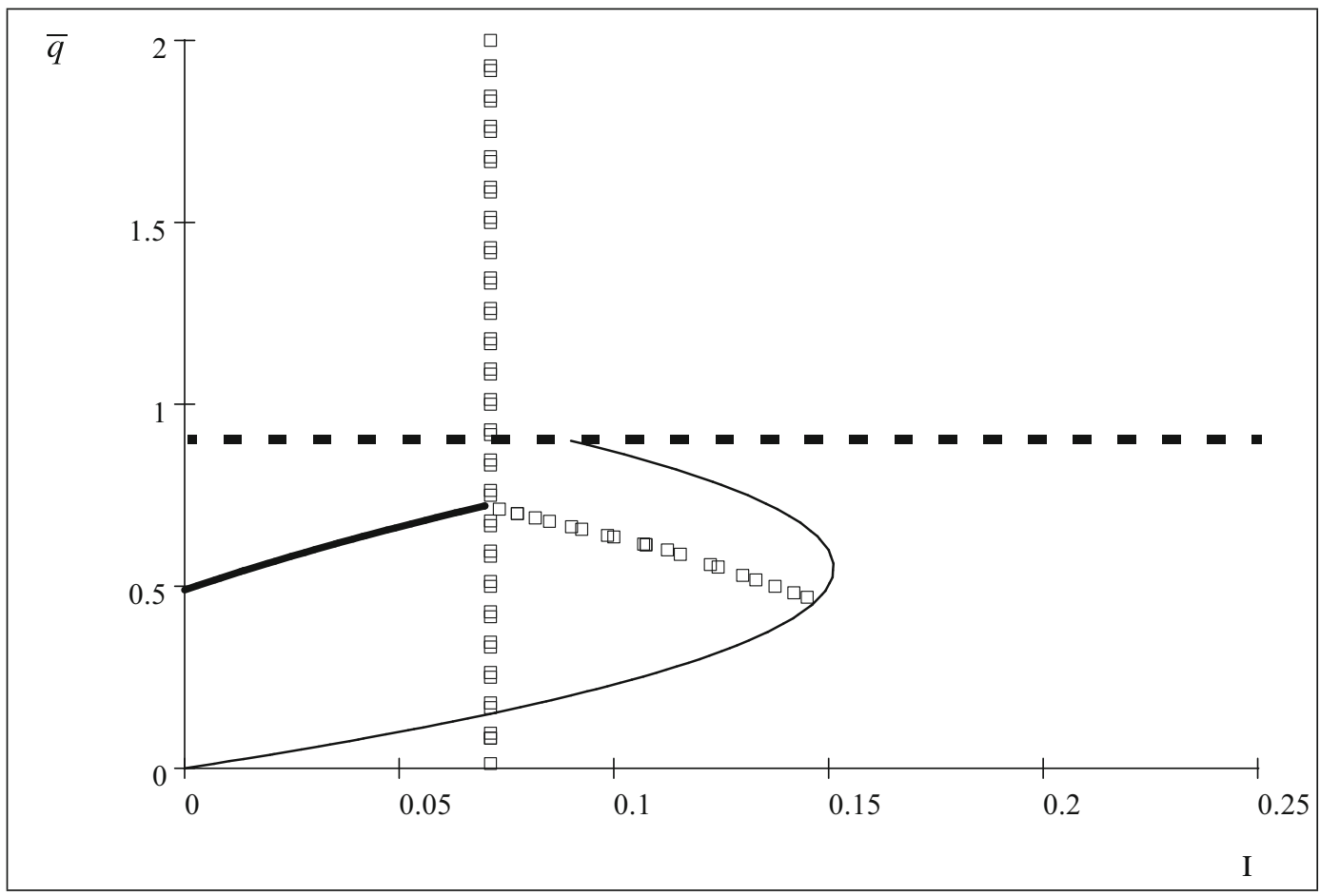

Fig. 2 Dash line: condition (17). Solid line: (18). Bold line: (19). Box line: (10). Diamond line: (16) 
firm initially begins its crowdfunding campaign and arranges a bank loan. An advantage of mixed financing compared to pure crowdfunding is that it adds some flexibility since it may help the firm with financing fixed costs $I$ given that the volume of crowdfunding is potentially limited. So going back to Fig. 2 we expect most help from mixed finance in the region where $\bar{q}$ is relatively small and where $I$ increases. To further highlight the difference between different strategies we assume that the direct cost of obtaining bank financing is $B$ (as was previously discussed this may include direct cost of preparing business plans and other documents, the time and effort spent on negotiating with banks etc. (see, e.g., PwC, 2008). We also assume that there is a cost $K$ of conducting a crowdfunding campaign (it may include such costs as a website creation, video preparation etc. (see, e.g., Bernardino \& Santos, 2020). A mixed financing has an advantage of crowdfunding in terms of learning market demand and potentially can reduce moral hazard problem related to crowdfunding by choosing the optimal proportion of bank financing and crowdfunding. The disadvantage, however, is the cost of obtaining both bank financing and conducting and developing a crowdfunding campaign.

Most proofs are similar to our previous analysis so we skip them for shortness. The outline of solution for the case $c=0$ is presented below. In a perfect market, firms financing strategy is irrelevant and firm's value equals $\frac{a^{2}}{4}-I$. In a market with moral hazard when the demand is known firms select Strategy 1 and the firm's value equals $\frac{a^{2}}{4}-I$. This is because the moral hazard problems affect either strategy 2 or 3 . Let us now consider the main case when the demand for the product is unknown and the entrepreneur's production decision is not contractible. For Strategies 1 and 2 the analysis is analogous to previous. Consider Strategy 3.

Proposition 5 Under Strategy 3: (1) if $\frac{(a-\bar{q})(a+\bar{q})}{4}>$ $I+2 K+2 B$ and $a>\bar{q}$ then $p_{c}=\frac{a-\bar{q}}{2}$ and the entrepreneur's profit equals: $\frac{(a-\bar{q})(a+\bar{q})}{8}-0.5 I-K-$ $B$; (2) if $\frac{(a-\bar{q})(a+\bar{q})}{4}<I+2 K+2 B$ or $a \leq \bar{q}$, Strategy 3 is not feasible and the entrepreneur's profit is 0 .

\section{Proof See Appendix 1.}

The result of Proposition 5 is that mixed financing relaxes one of the constraints for crowdfunding campaigns related to financing initial investment $I$. In some cases when pure crowdfunding is not feasible, mixed financing can be feasible but not vice versa. On the other hand the trade-off is related to increasing costs related to obtaining both a bank loan and creating a crowdfunding campaign.

Compared to Strategy 2, Strategy 3 can be optimal if $\bar{q}$ is sufficiently small or when $I$ is sufficiently large. Also as compared to Strategy 1, Strategy 3 will be preferred when $I$ is not sufficiently small or large. An example is presented below.

Consider the case:

$a>\bar{q}$

$\frac{(a-\bar{q}) \bar{q}}{2}-2 K>I$

$I<\frac{(a-\bar{q})(a+\bar{q})}{4}-2 K-2 B$

(the interpretation of these conditions is that if they hold, both crowdfunding and mixed financing are feasible). If $L \leq \frac{a^{2}}{4}-(a-\bar{q}) \bar{q}+4 K$ and respectively $\frac{(a-\bar{q}) \bar{q}}{2}-2 K<\frac{a^{2}}{8}-0.5 L$ that implies that $I<$ $\frac{(a-\bar{q}) \bar{q}}{2}-2 K<\frac{a^{2}}{8}-0.5 L$, then if the firm uses bank financing, the entrepreneur's profit equals

$\frac{a^{2}}{8}-I-0.5 L-2 B$

as follows from Proposition 2. If the firm uses crowdfunding the entrepreneur's payoff equals

$\frac{(a-\bar{q})(a+\bar{q})}{8}-0.5 I-K$

as follows from Proposition 3. And as follows from Proposition 5 if it uses mixed financing the entrepreneur's payoff equals

$\frac{(a-\bar{q})(a+\bar{q})}{8}-0.5 I-K-B$

The comparison of (23), (24) and (25) implies that bank financing will be chosen if and only if the following holds:

$\bar{q}>\sqrt{4 I+4 L-8 K+8 B}$

Otherwise Strategy 2 will be chosen. If $\frac{(a-\bar{q}) \bar{q}}{2}-$ $2 K<I<\frac{(a-\bar{q})(a+\bar{q})}{4}-2 K-2 B$ then Strategy 2 is not feasible. The comparison of (23) and (25) implies that bank financing will be chosen if and only if the following holds:

$\bar{q}>\sqrt{4 I+4 L-8 K}$ 


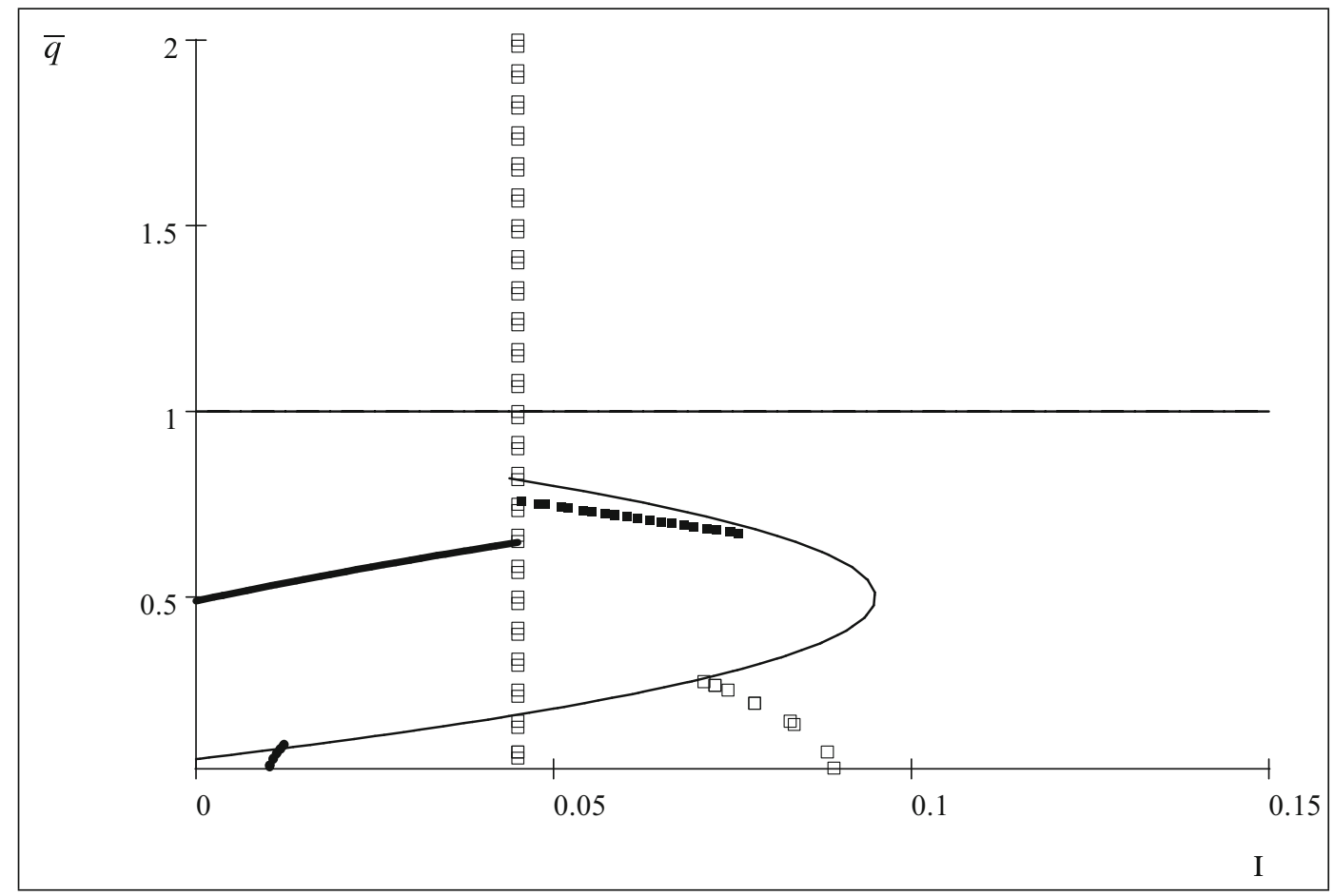

Fig. 3 Horizontal solid line: condition (20). Solid line: (21). Bold line: (27). Box line: (23) = 0. Diamond line: (22). Cross line: (24). Dot line: (26)

Figure 3 presents a graphical illustration of the above conditions for $a=1, B=0.05, K=0.03$ and $L=0.05$ (horizontal axes is $I$, vertical axes is $\bar{q}$ ).

Compared to Fig. 2, mixed financing is optimal in the area south of solid line between box line (condition (23)) and diamond line (condition (22)). It means in this area mixed financing is feasible while crowdfunding is not and it's more profitable than bank financing. As expected mixed financing is good when $\bar{q}$ is small. In this case under pure crowdfunding the firm may not be able to raise enough funds to finance the amount of investments required especially when $I$ is relatively large. When both $\bar{q}$ and $I$ are small, bank financing is optimal (small triangular area close to the zero point).

\section{Early demand signal and the role of campaign threshold}

One of our main results in the basic model is that if $\bar{q}$ is large enough, then crowdfunding becomes unfeasible because of moral hazard issues. In this section we analyze the role of the campaign threshold in helping to solve/mitigate this issue. In the basic model we did not focus on the details of crowdfunding campaign but just its main features as a reward-based campaign. The main engine that was driving the model's results was the connection between the outcomes of crowdfunding campaign and subsequent spot sales. In this section we will analyze the crowdfunding campaign in more details. First we assume that the firm can receive an early signal about the demand. Secondly the entrepreneur can establish a threshold. Recall that there are two main types of reward-based crowdfunding: AON ("all-or-nothing") where the campaign fails if an established target is not reached and KIA ("keepit-all") (for a review of different types of crowdfunding, see, e.g., Moritz and Block (2014) or Cumming et al. (2019)). Formally our main model can be interpreted as a KIA analysis. Basically the results can be applied to AON as well. The firm can rationally anticipate the amount of collected funds and establish the proper value for the threshold. For example in Section 3.3, an optimal threshold can have any value between $I$ and $\frac{a-c}{2} \frac{a+c}{2}$. An important difference between the basic model and one we consider in this section is 
the timing of decision-making when a threshold is established and when a signal about the demand is received. Here we assume that after the campaign threshold is reached, the entrepreneur makes decision whether to continue the project or terminate it and if he decides to continue he should decide whether the firm will stop the campaign and switch to spot market sales or continue the crowdfunding campaign (overfund ${ }^{25}$ ).

More formally we assume that the firm receives a signal when it collects an amount $T$. So the firm establishes a threshold equal to $\max \{I, T\}$, i.e., the amount of funds collected during the campaign should on the one hand cover the amount of investments required and on the other hand, it should be large enough to provide a credible signal about the demand (one can show that other thresholds are not optimal). ${ }^{26}$ The calculations for bank financing are similar to the basic model. Consider crowdfunding. If crowdfunding is chosen, the firm announces the crowdfunding (pre-sale) price $p_{c}$. If the amount of funds raised during the campaign is smaller than $T$ (i.e., $p_{c}\left(a-p_{c}\right)<T$ ), the campaign is terminated and money are returned to backers. If $p_{c}\left(a-p_{c}\right)>T$, then we assume that the campaign "pauses" when the required threshold is reached, i.e., when the number of pre-sales equals $q=T / p_{c}{ }^{27}$ The entrepreneur then has a choice of continue the campaign or to switch to spot sales (for shortness we consider $T \geq I$ that implies that the campaign threshold equals $T$; the analysis is similar for the case $T<I)$.

Below we discuss the solution of the model (for shortness we consider the case $c=0, L=0$ and $a<$ $\bar{q}$ : the latter provided most problems for crowdfunding in Sections 3 and 4 given the moral hazard problem). In a perfect market, the firm financing strategy is irrelevant and the firm value equals $\frac{a^{2}}{4}-I$. Under moral hazard when demand is known, bank financing is optimal. Let us now consider the main case when the demand for the product is unknown and the entrepreneur's production decision is not contractible. Production decision is similar to basic model.

\footnotetext{
${ }^{25}$ See, e.g., Hrůzová and Vaceková (2018).

${ }^{26}$ In this section we assume that $T$ is exogenously given based on the idea that a credible signal about the demand is received only when some minimal amount of funds is collected. Later we will discuss different types of signals.

${ }^{27}$ In reality as was discussed, the firm can establish a target (threshold) of funds raised and once this target is reached, the campaign pauses.
}

\subsection{Continuation/termination decision}

Consider firm decision after the signal is received. The entrepreneur has 3 options: to terminate the project, continue the campaign, or stop the campaign and switch to spot sales immediately. If the firm learned that $a=0$, the project will be terminated because the entrepreneur's profit cannot be positive. Consider a good case with positive demand. Two scenarios are possible.

1. $C>I$. Then if the firm withdraws from the project, backers get $C-I$ and the entrepreneur gets 0 . As was previously discussed, if the firm continues, then the entrepreneur's profit is either $\frac{\left(a-q_{c}\right)^{2}}{4}+\Pi_{1}$ or $\Pi_{1}$ where $\Pi_{1}=C-I$ (note that $\Pi_{1}>0$ because $C>I$ ). Since this is greater than 0 in either case, the entrepreneur will decide to continue. The choice between continue the campaign or stopping the campaign and moving to spot sales depends on the following condition:

$$
\frac{p_{c}^{2}}{4}+p_{c}\left(a-p_{c}\right)-I<\frac{\left(a-T / p_{c}\right)^{2}}{4}+p_{c} T / p_{c}-I
$$

The left-hand side (LHS) of (28) shows the firm profit if it continues the campaign. In this case $q_{c}=a-p_{c}$ because $a-p_{c} \leq \bar{q}$ and therefore $q_{s}=\frac{p_{c}}{2}$ etc.; the right-hand side (RHS) shows the firm profit if the campaign stops. In this case $q_{c}=T / p_{c}, q_{s}=a-T / p_{c}$. If (28) holds the firm will stop the campaign (and switch to spot sales) and vice versa. If (28) does not hold and the firm continues its crowdfunding campaign, the following should hold: $p_{s}=a-q_{s}-q_{c}=\frac{a-q_{c}+c}{2}=$ $\frac{p_{c}+c}{2}$ and the no-arbitrage condition (13) that can be written as $\frac{p_{c}+c}{2} \geq p_{c}$ or $p_{c} \leq c$ that does not hold because in this case the firm will not create any profit.

2. $C<I$. Then the firm cannot continue. So the project is terminated and the entrepreneur's profit is 0 . In fact in this case, no one will invest in crowdfunding and the campaign fails.

\subsection{Initial financing}

Initially the firm sets the price $p_{c}$ to maximize the entrepreneur's expected profit $\Pi$. Two scenarios are possible depending on the expected decisions 
at production stage and continuation stages. If the entrepreneur anticipates stopping the campaign after the target is reached and also $q_{s}>0$ then initially he maximizes $\Pi=0.5\left(\frac{\left(a-\frac{T}{p_{c}}\right)^{2}}{4}+T-I\right)$ subject to no-arbitrage condition

$p_{s}=a-q_{s}-q_{c}=\frac{a-\frac{T}{p_{c}}}{2} \geq p_{c}$

and also $a \geq q_{c}$ and $p_{s}<a$. The last condition can be rewritten as $0 \leq a+q_{c}$ that holds. If the entrepreneur expects $q_{s}=0$, then his expected profit equals $\Pi=$ $0.5(T-I)$ that is smaller than in the scenario $q_{s}>0$.

If the entrepreneur anticipates the campaign continuation and $q_{s}>0$ then he anticipates $q_{c}=$ $a-p_{c}$ and then initially he maximizes $\Pi=$ $0.5\left(\frac{p_{c}^{2}}{4}+p_{c}\left(a-p_{c}\right)-I\right)$ subject to $p_{c}\left(a-p_{c}\right) \geq$ $T$, and no-arbitrage condition

$p_{s}=a-q_{s}-q_{c}=\frac{p_{c}}{2} \geq p_{c}$

Equation (30) does not hold because under crowdfunding $p_{c}>0$.

If the firm anticipates stopping the campaign, two situations are possible.

1. $\quad a<q_{c}=\frac{T}{p_{c}}$. This implies $T>a p_{c}$. This cannot hold because in order for the campaign to succeed one needs $p_{c}\left(a-p_{c}\right)>T$. Combining with previous inequality we get $p_{c}\left(a-p_{c}\right)>T>a p_{c}$ that does not hold because $p_{c}\left(a-p_{c}\right)<a p_{c}$.

2. $a>q_{c}=\frac{T}{p_{c}}$. Since in this scenario the firm will stop the campaign (28) should hold that implies:

$$
3 p_{c}^{4}-4 a p_{c}^{3}+a^{2} p_{c}^{2}-2 T p_{c}+T^{2}+4 T p_{c}^{2} \geq 0
$$

Proposition 6 If the signal about demand is received when the required amount of pre-sales is reached/not reached and the entrepreneur can switch to spot sales after the target is reached, crowdfunding can be feasible even when $a<\bar{q}$. Furthermore, in some cases it can be optimal.

Proof Follows from above. Indeed suppose $a=2$, $I=0.1, T=0.1, p_{c}=0.6$. The non-arbitrage conditions (29) and (31) hold. Furthermore the firm objective function with crowdfunding is greater than with bank financing. Indeed with bank financing it is $\frac{a^{2}}{8}-I$ (Proposition 2) and equals 0.4 while with crowdfunding it is $0.5\left(\frac{\left(a-\frac{T}{p_{c}}\right)^{2}}{4}+T-I\right)=0.45$. Also by continuity, this should hold when the parameters values are close.

The result of Proposition 6 is quite general and holds under different assumptions about different types of signal about market demand. We will consider a different type of signal in next section. Also the result would hold if for example we would assume that $T$ is endogenous. An interpretation is that the firm receives a signal when a threshold established by the firm is reached (or not) regardless its size (even for example if the threshold is very small). ${ }^{28}$ As we mentioned previously in our main analysis the assumption was that in order to receive a credible signal the firm needs to collect a minimal amount that does not depend on the firm decision(s).

\subsection{A different signal}

In previous section, the firm receives the demand signal after the amount of collected funds reaches the required target. In this section we assume that the demand signal can be received only when the number of items sold during pre-sales is large enough. In addition we also assume that initially the firm can commit to a long campaign (an interpretation is an AON campaign with a high threshold value or a KIA campaign) or select a short campaign (AON campaign with a relatively small threshold, i.e., where the target is just large enough to receive a demand signal and cover the investment cost) and potentially decide to stop the campaign after receiving the signal. The purpose of this section is to demonstrate that most previoulsy obtained results hold under different assumptions and secondly to obtain a closed form solution when the firm has a choice between different types of crowdfunding.

Similar to Section 4, to finance the project, the firm can either use a bank loan (Strategy 1), crowdfunding (Strategy 2) or a mix of both (Strategy 3). If strategy 2 or 3 are chosen, the firm can receive a signal about demand if the number of pre-orders reaches $t$. The

\footnotetext{
${ }^{28}$ In existing literature an indicator whether the campaign threshold was reached/not reached is recognized as the main information about the campaign quality/success and respectively about the demand for the product that is one of the main measures of campaign success (see, e.g., Kim et al., 2018).
} 
campaign pauses after the demand signal is received. The firm then can decide if it wants to continue the campaign, to end the campaign and move to production stage or to liquidate the firm. In the first case, the campaign is extended, i.e., the firm collects the total number of pre-orders equal to $q=a-p_{c}$. Initially the firm sets up the price $p_{c}$ and select the threshold $T$ such as $p_{c} t=T$ and $a-p_{c} \geq t$. The latter implies that if $p_{c}$ is too large and the number of items pre-sold during crowdfunding campaign is too small, the signal is not credible.

Similar to the basic model, in a perfect market, the firm's capital structure is irrelevant and firm's value equals $\frac{a^{2}}{4}-I$ (for shortness we consider the case with $c=0, L=0$ and $a<\bar{q}$; as was previously mentioned the latter implied most problems for crowdfunding in Sections 3 and 4 given the moral hazard problem). Also similar to basic model, in a market with moral hazard when the demand is known firms select Strategy 1 and the firm's value equals $\frac{a^{2}}{4}-I$.

Consider the main case when the demand for the product is unknown and the entrepreneur's production decision is not contractible. Bank financing is identical to the basic model. So under Strategy 1: (1) if $\frac{a^{2}}{8} \geq I, F=2 I$ and the entrepreneur's profit equals: $\frac{a^{2}}{8}-I ;(2)$ if $\frac{a^{2}}{8}<I$, Strategy 1 is not feasible and the entrepreneur's profit is zero. This is a simple application of Proposition 2. Also a long crowdfunding campaign and a mixed financing with a long campaign are not feasible when $a<\bar{q}$ (similar to the main model).

Consider the short campaign. Production decision is similar to basic model. Consider the firm decision after the signal is received. The entrepreneur has 3 options: to terminate the project, continue the campaign, or stop the campaign and switch to spot sales immediately. If the firm learned that $a=0$, the project will be terminated because the entrepreneur's profit cannot be positive. Consider a good case with positive demand. Two scenarios are possible.

1. $C>I$. Then if the project is terminated, backers get $C-I$ and the entrepreneur gets 0 . If the firm continues and switches to spot sales, then the entrepreneur's profit is $\frac{\left(a-q_{c}\right)^{2}}{4}+\Pi_{1}$. where $\Pi_{1}=$ $C-I$. The entrepreneur can also decide to continue the campaign. Since $a-p_{c} \leq \bar{q}$ the choice between continue the campaign or stopping the campaign and moving to spot sales depends on the following condition:

$$
\frac{p_{c}^{2}}{4}+p_{c}\left(a-p_{c}\right)-I<\frac{(a-t)^{2}}{4}+p_{c} t-I
$$

LHS shows the firm profit is it continues the campaign. In this case $q_{c}=a-p_{c}$ because $a-p_{c} \leq \bar{q}$ and therefore $q_{s}=\frac{p_{c}}{2}$ etc.; RHS shows the firm profit if the campaign stops. In this case $q_{c}=t$, $q_{s}=\frac{a-t}{2}$. If (32) holds the firm will stop the campaign and vice versa. If the campaign continues, the following should hold: $p_{s}=a-q_{s}-q_{c}=$ $\frac{a-q_{c}}{2}=\frac{p_{c}}{2}$ and the no-arbitrage condition (13) that can be written as $\frac{p_{c}}{2} \geq p_{c}$ that does not hold because in this case the firm will not create any profit so a scenario with continuation should not be considered by the entrepreneur when $a<\bar{q}$.

2. $C<I$. Then the firm cannot continue. So the project is terminated and the entrepreneur's profit is 0 . In fact in this case, no one will invest in crowdfunding and the campaign fails.

Initially the firm sets the price $p_{c}$ to maximize the entrepreneur's expected profit $П$. The entrepreneur anticipates stopping the campaign after the target is reached and if he also anticipates $q_{s}>0$ then he maximizes $\frac{(a-t)^{2}}{4}+p_{c} t-I$ subject to no-arbitrage condition

$p_{s}=a-q_{s}-q_{c}=a-\frac{a-t}{2}-t=\frac{a-t}{2} \geq p_{c}$,

$a \geq q_{c}$ and $p_{s}<a$. This is because as was argued previously if $a=0$, the entrepreneur's profit is zero. The last condition can be rewritten as $0 \leq a+q_{c}$ that holds.

If the entrepreneur expects $q_{s}=0$, then his expcted profit equals $\Pi=0.5\left(p_{c} t-I\right)$ that is smaller than under the scenario with $q_{s}>0$.

Two cases exist.

1. $a<q_{c}=t$. This cannot hold because in order for the campaign to succeed one needs $p_{c}\left(a-p_{c}\right)>$ $t p_{c}>a p_{c}$ that does not hold.

2. $a>q_{c}=t$. Equation (32) implies:

$$
a-t \geq p_{c} \geq \frac{a-t}{3}
$$

The non-arbitrage conditions are (33) and (34). Optimal $p_{c}=\frac{a-t}{2}$ (the constraints (conditions (33) and (34)) are crucial here since the objective function in increases in $p_{c}$ so the solution is the maximal 
possible $p_{c}$ that satisfies both no-arbitrage conditions). Initially, the entrepreneur's objective function is:

$$
\begin{aligned}
\Pi & =0.5\left(\frac{(a-t)^{2}}{4}+p_{c} t-I\right) \\
& =0.5\left(\frac{(a-t)^{2}}{4}+\frac{a-t}{2} t-I\right)= \\
& =\frac{a^{2}-t^{2}}{8}-0.5 I
\end{aligned}
$$

It works if

$\frac{a-t}{2} t \geq I$

Under mixed financing the firm's profit is

$\frac{a^{2}-t^{2}}{8}-0.5 I-B$

It is smaller than (35) because of the cost of obtaining a bank loan. The advantage of mixed financing compared to crowdfunding is that the condition (36) does not have to hold.

Finally compare different financing strategies. Under bank financing according to Proposition 2 the firm's profit is

$$
\frac{a^{2}}{8}-I-B
$$

Note that if

$$
\frac{t^{2}}{4}>I+B
$$

bank financing is more profitable than Strategy 2 and if

$$
\frac{t^{2}}{4}>I
$$

bank financing is more profitable than Strategy 3.

Proposition 7 In a market with moral hazard and uncertain demand if $a<\bar{q}, B=0$ and $t \leq \frac{2 a}{3}$ : (1) if $\frac{t^{2}}{4}>I$ then the firm selects Strategy 1 , $D=I, F=2 I$ and the firm's profit is $\frac{a^{2}}{8}-I$; (2) if $\frac{t^{2}}{4}<I<\frac{a-t}{2} t$ then the firm selects Strategy 2 (short campaign), $p_{c}=\frac{a-t}{2}$ and the firm stops the crowdfunding campaign after receiving information about demand, and the entrepreneur's expected profit equals $\frac{a^{2}-t^{2}}{8}-0.5 I$; (3) if $\frac{a-t}{2} t<I<\frac{a^{2}-t^{2}}{4}$ then the firm selects Strategy 3 (with short campaign), $p_{c}=\frac{a-t}{2}, D=I-\frac{a-t}{2} t$ and the firm stops the crowdfunding campaign after receiving information about demand, and the entrepreneur's expected profit equals $\left.\frac{a^{2}-t^{2}}{8}-0.5 I ; 4\right)$ if $I>\frac{a^{2}-t^{2}}{4}$, the project will not be undertaken and the entrepreneur's profit equals 0 .

If $a<\bar{q}, B=0$ and $\frac{a}{\sqrt{2}} \geq t>\frac{2 a}{3}$ : (1) if $\frac{t^{2}}{4}>I$ then the firm selects Strategy $1, D=I, F=2 I$ and the firm's profit is $\frac{a^{2}}{8}-I$; (2) if $\frac{t^{2}}{4}<I<\frac{a^{2}-t^{2}}{4}$ then the firm selects Strategy 3 (with short campaign), $p_{c}=\frac{a-t}{2}, D=I-\frac{a-t}{2} t$ and the firm stops the crowdfunding campaign after receiving information about demand, and the entrepreneur's expected profit equals $\left.\frac{a^{2}-t^{2}}{8}-0.5 I ; 4\right)$ if $I>\frac{a^{2}-t^{2}}{4}$, the project will not be undertaken and the entrepreneur's profit equals 0 .

If $a<\bar{q}, B=0$ and $t>\frac{a}{\sqrt{2}}:$ (1) if $\frac{t^{2}}{4}>I$ then the firm selects Strategy $1, D=I, F=2 I$ and the firm's profit is $\frac{a^{2}}{8}-I$; (2) if $\frac{t^{2}}{4}<I$, the project will not be undertaken and the entrepreneur's profit equals 0 .

Proof Follows from above by comparing firm's values in different scenarios.

Figure 4 illustrates Proposition 7 for the case when $B>0$. Here $t=0.5, B=0.03$ and $\bar{q}=1$.

In the area above solid line (condition (38)) and to the left of box line (39)), bank financing is optimal. In the area between solid and diamond lines (condition (36) crowdfunding is optimal, in the area between diamond line and dot line (condition (37)) to the right of their intersection, mixed financing is optimal and below the dot line as well below the diamond line to the left of their intersection no financing is feasible. To the right of box line and above the diamond line crowdfunding is optimal. One of the interpretations of these results is that for a given value of $I$, projects with highest $a$ will look for bank financing, next for crowdfunding and next for mixed financing. On the other hand for a given value of $a$, firms with highest $I$ will look for mixed financing, then crowdfunding and then bank financing. The case with $B=0$ (Proposition 7) has similar interpretations. Conditions (35), (37), Proposition 7 and Fig. 4 illustrate another point that smaller $t$ is beneficial for crowdfunding. It is intuitive since it means that the firm is able to acquire an early credible signal. Large $t$ requires a longer campaign and creates more problems for crowdfunding related to moral hazard issues at production stage (it reduces the objective function in (35) and (37)).

Similar results can be obtained in Section 4.2 by jointly analyzing AON and KIA campaigns but the calculations are significantly longer. 


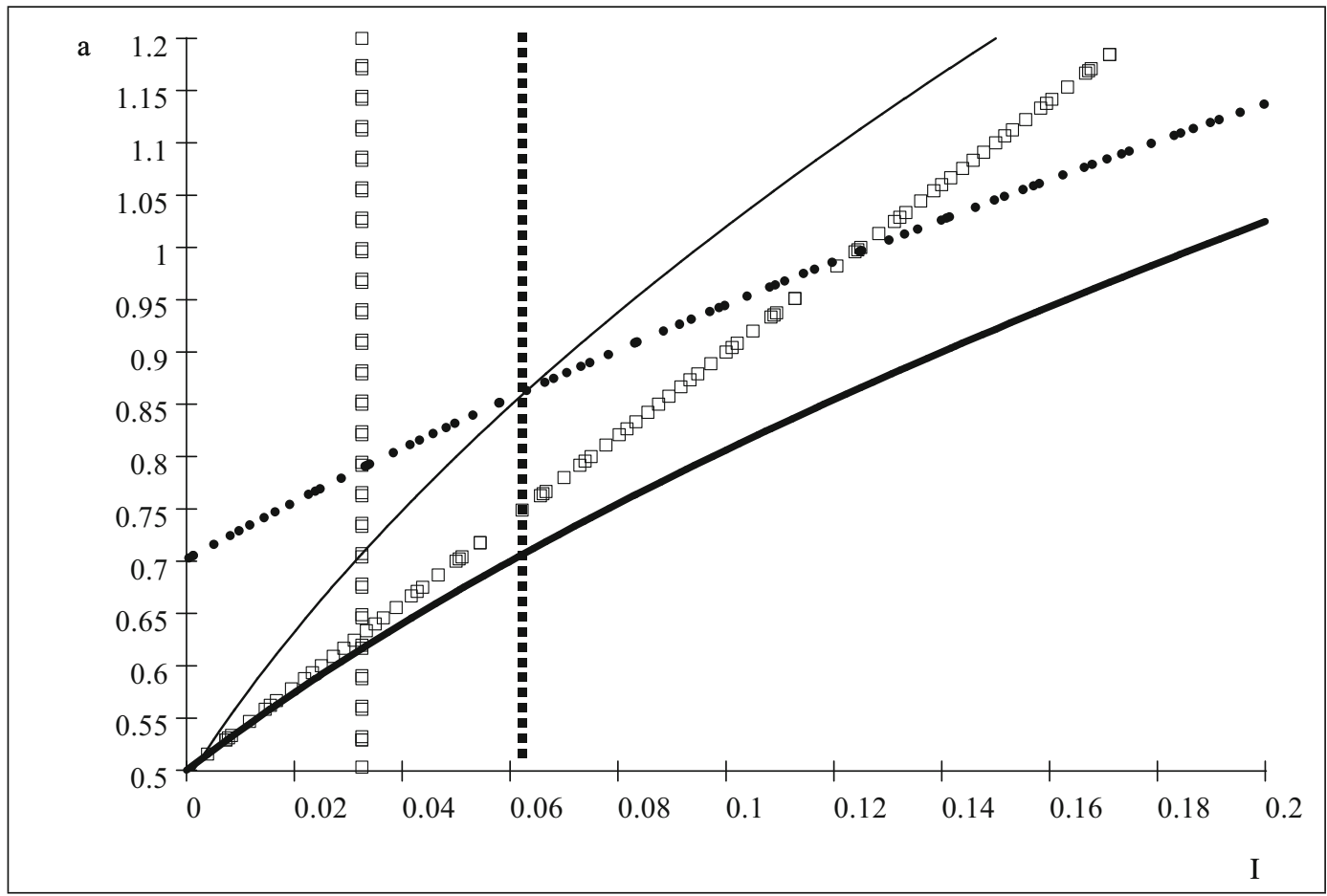

Fig. 4 Solid thin line: condition $(38)=0$. Diamond line: (36). Bold line: $(35)=0$. Cross line: (40). Box line: (39). Dot line: (37) $=0$

\section{The model implications}

Overall the paper suggests that the moral hazard problem related to the choice of production quantity creates a problem for crowdfunding. In many cases it makes the campaign infeasible (non-sustainable) from no-arbitrage condition point of view. This might be one of the explanations for why bank financing is still much more widely used compared to crowdfunding despite facts that bank financing is costly and that it is hard to obtain by low-quality firms, SMEs, innovative firms etc. and despite the fact that crowdfunding provides signals about market demand.

Secondly, the paper suggests some explanations for why crowdfunding campaigns are small even if the market limitations are weak, or even inexistent. This suggests that with fintech development and deeper internet penetration in day-to-day lives of people around the world when more and more people and potential customers will be familiar with crowdfunding one still should not expect that by volumes crowdfunding will quickly catch up with bank financing. This result holds under different types of assumptions about the type of signals about demand. The reason for this is not the existence of natural crowdfunding limitations $(\bar{q})$ per se but mostly related to the value of $\bar{q}$ and quite surprisingly the main point is that crowdfunding is not feasible when $\bar{q}$ is large (Sections 3 and 4 (Proposition 3)). This is because when $\bar{q}$ is large the crowdfunding campaign is not feasible due to moral hazard issues. This is consistent with observed evidence on crowdfunding that crowdfunding campaigns are typically small (see, e.g., Bernardino and Santos (2020)). This is also consistent with the spirit Belleflamme et al. (2014) and Miglo and Miglo (2019) in that large projects should not use crowdfunding. An indirect evidence that is consistent with this phenomenon is that there is a negative correlation between the campaign size and its degree of success (see, e.g., Mollick (2014)).

The paper also explains how can a campaign threshold help the firm mitigate in some cases problems related to moral hazard issues. This is consistent with a widespread usage of AON method ("all-ornothing" method used among others by Kickstarterthe largest crowdfunding platform).

Consistent with observed evidence on crowdfunding we find that crowdfunding campaign are typically 
short (Proposition 4). In Section 5 where the firm can establish a threshold and receive a signal about the demand when the threshold is reached a small/short campaign will typically be chosen over large/long campaigns even when $\bar{q}$ is infinitely large. In practice we know that crowdfunding is a way of raising funds quickly and the average time of crowdfunding campaign is much shorter than, for example, that of classical equity issues. ${ }^{29}$ An indirect evidence that is consistent with this phenomenon is that there is a negative correlation between the campaign duration and its degree of success (see, e.g., Lukkarinen et al., 2016; Mollick, 2014).

The effect of investment size $(I)$ is in most cases non-linear. In some cases when crowdfunding is unfeasible (e.g., when $\bar{q}$ is large as in Sections 3 and 4 ), bank financing is the only option for the firm for any value of $I$. In some cases mixed financing is optimal when $I$ is large (Section 4 and Proposition 7). The reason is that under bank financing the value loss from a large amount of investment is greater than under crowdfunding due to unknown demand. Under crowdfunding, the project may not be feasible when $I$ is large. The latter happens especially when $\bar{q}$ is small and if the amount of investment is sufficiently high, crowdfunding should not be used (without bank financing) since the amount of funds raised in the beginning of campaign will not cover the required amount of fixed investments. In some cases (e.g., when $\bar{q}$ is in the medium range), crowdfunding can be optimal for large projects because it can be cheaper than mixed financing. These predictions have not been directly tested in existing literature however it seems to be consistent with some available evidence. The former, for example, explains why a large group of SMEs uses bank financing as their major source of finance (as was mentioned in Section 1). If we compare pure crowdfunding and a mix of bank financing and crowdfunding then the latter should be used with a higher amount of investments (the case when bankruptcy costs are relatively large). This is consistent with overall evidence that usually the average crowdfunding campaign size is smaller than that of bank financing. ${ }^{30}$

\footnotetext{
${ }^{29}$ For example, it was found in Salahaldin et al. (2019) that the average campaign duration is between 30 and 90 days.

${ }^{30}$ See, e.g., https://www.british-business-bank.co.uk/research/ $\mathrm{sbfm} /$
}

The model explains why a mixed financing (a bank loan and crowdfunding) can be used in equilibrium. This is a new result compared to existing literature that studies the firm financing involving crowdfunding and bank financing. It helps with explaining cases that were discussed in Section 1. Also in contrast to some previous papers the present paper suggests that crowdfunding and bank financing can be complements (that is consistent with, e.g., Cole et al., 2019) and that they are not necessarily substitutes (as in, e.g., $\mathrm{Xu}$ (2018)). ${ }^{31}$ We also see limitations of mixed financing that explains perhaps why it is not widely used.

The effects of profitability and the market size are also non-linear in most cases. As predicted by Proposition 7 , for a given level of investment, firms of higher quality apply for bank financing.

The effect of $\bar{q}$ (potential market size that can be reached during crowdfunding campaign) and the likelihood of using crowdfunding are also non-linear in most cases. On the one hand $\bar{q}$ should be large enough to make sure that the firm is able to finance initial investment $I$. It may be difficult if $\bar{q}$ is small and $I$ is sufficiently large. However most importantly $\bar{q}$ should be small enough because large $\bar{q}$ makes crowdfunding infeasible due to no-arbitrage condition violation.

Our paper also predicts that under crowdfunding or mixed financing (note that in either case the firm uses reward-based crowdfunding) prices are lower than under bank financing. This has not been tested. In a similar spirit some related papers (e.g., Miglo and Miglo, 2019) find that prices can be higher and quantity produced can be lower under equity-based crowdfunding than under reward-based crowdfunding. This is consistent with Paakkarinen (2016) that noted that in contrast to reward-based crowdfunding, equitybased crowdfunding may have fewer customers, but higher margins.

Based on our analysis a potential policy implication has emerged. If by law companies would have to limit the size of their campaigns or/and stop their

\footnotetext{
${ }^{31}$ Further our model is also consistent with staged financing where initially the firm uses crowdfunding and then uses bank financing (see, e.g., p. 13). In fact in many cases when $\bar{q}$ is sufficiently small, the entrepreneur who selected crowdfunding for financing initial costs will select debt for financing variable costs (bank financing will not have same costs as at initial stage since the banker will see that the firm undertook crowdfunding and received a market approval or learned the market wisdom).
} 
campaigns after the target is reached ${ }^{32}$ it would help to mitigate the extent of potential moral hazard problems related to the choice of production scale and respectively it would reduce the chances of no-arbitrage condition violation that in turn would imply that potential backers will have more trust in the feasibility of the campaign. So ultimately this should increase the interest to crowdfunding and the extent of its usage by entrepreneurs. It may be appropriate in current conditions given that the amount of bank loans by far exceeds that of crowdfunding.

\section{Model extensions and robustness}

\subsection{Positive demand in "bad" scenario}

In our model we assumed that the demand is absent in "bad" scenario. An interesting extension is related to the case when the demand is low but positive. In addition we consider the case when the investment must be made before the signal about the demand is received. This extension potentially involves debt renegotiation (in low demand scenario) and potentially more interactions between crowdfunders and creditors. ${ }^{33}$ Consider the model described in Section 4. Suppose that firm demand is $q=a-p$, where $a=a_{h}$ with probability $50 \%$ and $a=a_{l}$ otherwise, $a_{h}>a_{l}$. Also $\frac{a_{l}^{2}}{4}<I$ (i.e., the project has negative NPV in a low demand scenario). If Strategy 3 was used then after receiving information about demand, the firm can renegotiate existing debt (that can include changes in the interest rates; let $F_{2}$ be the face value of debt after renegotiation ${ }^{34}$ ). The firm can also file for a bankruptcy/reorganization or be liquidated at this point.

This analysis has several interesting points. Very generally, it confirms several results from the basic model: the firm undertakes the project if and only if the amount of investment is sufficiently low; the

\footnotetext{
${ }^{32}$ In the spirit of Belavina et al. (2020). See also https://knowledge.wharton.upenn.edu/article/protect-crowdfun ding-backers-fraud/

${ }^{33}$ In the basic model when demand is absent in "bad" scenario any renegotiation does not create any social surplus since the firm revenue is zero anyway. Formal calculations are omitted for brevity.

${ }^{34}$ See, e.g., Tuo et al. (2019) for a related discussion.
}

optimal crowdfunding price is often $p_{c}=\frac{a_{h}}{3}$ etc. If we compare all three possible financing strategies (formal calculations are omitted for brevity) another basic result is confirmed for the case when $\bar{q} \geq a$ in that if the amount of investment is large the firm uses a mixed financing, if it is in intermediate range then crowdfunding should be used and if it is low then a bank financing should be used. Also it explains why the crowdfunding price is lower than the spot price. Indeed in the scenario when $a_{l}$ is sufficiently high, the optimal crowdfunding price is $p_{c}=\frac{a_{l}}{3}$. This is because it is more profitable for the firm to continue business in both scenarios (high- and lowdemand) even though in the low demand scenario it will involve a renegotiation of debt conditions). In this case in a high demand scenario, spot price equals $\frac{3 a_{h}+a_{l}}{12}$ that is higher than crowdfunding price. This is consistent with observed evidence where rewardbased crowdfunding is usually accompanied by some benefits including possible price discounts. Secondly if $a_{l}$ increases (in extreme case when $a_{l}=a_{h}$, there is no demand uncertainty at all) it favors bank financing. It is consistent with $\mathrm{Xu}$ (2018). On the other hand if the cost of debt financing increases (e.g., bankruptcy costs) then it favors Strategy 2. Xu (2018) finds in similar spirit that an increase in interest rates favors crowdfunding and vice versa.

To some extent this explains the point about mixed financing sustainability element mentioned in Section 1. Indeed under mixed financing the firm avoids costly default stages in any phase of its project. In case of low demand after the signal is received the firm debt is privately renegotiated so bankruptcy costs related to public bankruptcy are avoided etc. that is not always the case with bank financing.

\subsection{No-arbitrage condition and crowdfunding discounts}

One of the features of our model is the non-arbitrage condition: $p_{c} \leq p_{s}$. Otherwise, the backers would not be interested in participating in crowdfunding. This is consistent with existing literature in the field (see, e.g., Belleflamme et al., 2014). For a good discussion of practical cases related to this condition, see, e.g., Beier et al. (2019). In some cases in equilibrium we have $p_{c}<p_{s}$ (e.g., Sections 3 and 4 ) that is consistent with widely used practice of crowdfunding discounts for backers. Also as was previously mentioned, in the 
basic model we do not assume that there are costs of waiting (as in Miglo, 2020a). So although nonarbitrage condition must hold, there is no "penalty" (crowdfunding discounts) for the firm if $p_{c}=p_{s}$. One can assume that there is a cost of waiting and crowdfunding implies an additional $\operatorname{cost} \beta$ for waiting. Then quantitatively calculations may slightly differ but most results will hold qualitatively. For example as was previously mentioned, the net price for backers is $p_{c}-\beta$. However the no-arbitrage condition is still $p_{c} \leq p_{s}$ that does not hold for cases in Section 3 and others when, for example, $\bar{q}$ is sufficiently large etc.

\subsection{Different approaches to model bank loans}

Our model is based on a moral hazard problem, i.e., the entrepreneur takes actions which cannot be directly controlled by the providers of funds. The main trade-off is that bank financing is more expensive but provides better opportunities to deal with the moral hazard problem, while crowdfunding is potentially limited in size but provides a signal about market demand. One can consider different modifications of the model by introducing different timing of events or different decision-making roles for different participants, e.g., a scenario where the firm applies for a bank loan first and then the bank considers an application and may approve it or reject it; if rejected the firm selects crowdfunding. If condition (12) is satisfied, the bank will approve the contract because in this case the bank expected return should cover the bank investment cost. Otherwise the loan will not be approved. So the model results will not be affected. One can further assume that the firm can use crowdfunding after the loan is rejected. But again this does not affect the main result since the firm will rationally anticipate that the loan application will fail and will select crowdfunding initially since its value will be higher than its value if the firm uses crowdfunding after the loan is rejected by the amount $B$. One can further assume that for example the banking technology is not completely known by the applicant at the moment they apply for a loan and there are say "tough" banks which have a high probability of rejecting a loan and "soft" banks that are more likely to accept it and so there is an asymmetric information element where banks, for example, can signal their types by offering different types of contract. This is an interesting line for future research. In addition, one can assume that the firm has initial assets-in-place. It will not affect the outcome of crowdfunding campaign but it can affect the modelling of bank loan because one can for example assume that the loan has two parts (an interest rate and a collateral requirement) since existing assets can be used as a collateral (see, e.g., Bester (1987)). Although quantitatively some calculations may change but qualitatively the results will not be affected since the availability of collateral will be reflected in the cost of bank financing. It will reduce the cost of bank loan but the cost of bank loan is captured in the model by variables $B$ and $L$. One can further complicate the model by introducing, for example, asymmetric information about firm's quality (for example, about the firm cost). It is an interesting direction for future research but it is beyond the scope of our paper.

\subsection{Other financing strategies}

Potentially one can include other types of financing into consideration, e.g., equity-based crowdfunding or debt-based crowdfunding. ${ }^{35}$ Note however that these two types of crowdfunding have a lot in common with traditional debt and equity financing so it is hard to estimate the marginal benefit of these inclusions given the vast amount of literature analyzing debt/equity choice or literature analyzing different kinds of debt. Also the available evidence regarding mix of crowdfunding and bank financing as an innovative strategy seems to be mostly pointing towards reward-based crowdfunding (see, e.g., Ulule mentioned in Section 1). From our point of view a mix of donation-based crowdfunding and bank financing can be seen as promising line for future research given that this type of crowdfunding in general has not been much analyzed in literature and it seems like it takes place in practice (see, for example, cases with private individuals including superstars or students ${ }^{36}$ using this combination of financing). We leave this line for future research.

\footnotetext{
${ }^{35}$ For a literature on equity-based crowdfunding see, for example, Ahlers et al. (2015), Vulkan et al. (2016), Ahlstrom et al. (2018), Estrin et al. (2018), Kleinert et al. (2020), Mochkabadi and Volkmann (2020), and Miglo (2020b). For debt-based crowdfunding see, for example, Lenz (2016) and Kgoroeadira et al. (2019).

${ }^{36}$ https://www.bbc.co.uk/news/uk-53857694.
} 
In our model we focus on reward-based crowdfunding and bank financing. As was mentioned previously traditionally these two types of financing are deeply connected to one of the main feature of our model namely the choice of production strategy. Other types of financing are also popular among innovative firms, SMEs, firms operating in uncertain environments, start-ups etc. including venture capital (VC) finance and angel finance. Usually in theoretical models venture capital finance is analyzed from the point of view of its impact on moral hazard issues related to the choice of effort by entrepreneur which is different from the focus of present paper. Different fractions of ownership (which usually happens under VC) provide different incentives for the entrepreneur. Furthermore some times a double moral hazard is analyzed where the venture capital firm also provides an effort (see, e.g., De Bettignies and Brander, 2007; Arcot, 2014). $\mathrm{VC}$ advantage is that venture capital firm provides effort and can improve the entrepreneur effort but it does not provide a signal about demand as much as crowdfunding (Schwienbacher, 2018). To incorporate an entrepreneurial effort in the model is an interesting direction for future research.

Note also that simple inclusion of equity financing should not affect our main ideas. For example the production decision should not be affected. Indeed suppose a firm sells a fraction $\alpha$ of equity. Then the production decision (under strategy 1 or 3 ) is to select $q$ that maximizes

$(1-\alpha)\left(q(a-q-c)+\Pi_{1}\right)$

The optimal solution is $q=\frac{a-c}{2}$ like in our model. As was previously mentioned one can further complicate the model by including a cost of personal effort by the entrepreneur. This is an interesting direction for future research. At this point however it is hard to estimate the marginal benefit of such an inclusion at the expense of significant model complication. Further extensions are possible by considering asymmetric information between entrepreneur and investors etc. This would potentially lead to a set-up where traditional pecking order and signalling ideas can take place and so depending on the form of equity financing, bad quality entrepreneurs can select equity financing (or equity-based crowdfunding etc.) compared to debt financing etc.

\subsection{Empirical tests}

Future empirical tests of our model should be focused on analyzing the connections between the entrepreneur's choice (that can be a dependent variable) between crowdfunding and bank financing and such variables as $I$ (project size), $a$ (profitability), $c$ (production costs), $\bar{q}$ (market size) etc. and should also include variables $B$ and $L$ describing the cost of bank financing/degree of financial constraint etc. Firms without prior experience and assets (or with low prior profitability) and/or without collateral will have a higher cost associated with bank loans and respectively a higher probability of being rejected. If a research finds that in these regressions the most/only important variables are $B$ and $L$ and variables $I, a$, $\bar{q}$ and $c$ are unimportant and further say firms with high values of $B$ and $L$ (i.e., having difficulties with obtaining bank loans) select crowdfunding and vice versa that would be consistent with the idea that if firm has access to bank loan that it would definitely select a bank loan and otherwise it would turn to alternative finance, e.g., crowdfunding. However our paper suggests that other variables should also be important in this choice. Off course to test a theoretical model represents a challenging issue in practice because many data are not directly observable and many data are missing especially for start-up companies. Some papers analyze future unobservable costs (soft information) that often are used by banks especially for start-up firms Lehmann, 2003; Berger et al., 2005; Gonçalves et al., 2014; Liberti \& Petersen, 2019 etc.). When no direct data is available, a survey can be used (see, e.g., Beck et al. 2006). Also the cost of bank financing can be proxied by the number of failures in banking industries or other difficulties of obtaining a bank loan related to the bank situation (in the spirit of Blaseg \& Koetter, 2016; Xu, 2018 or Cole et al., 2019). We have also included some examples of empirical papers conducting tests of theories/ideas that include bank loans to SMEs and having to deal with potential endogeneity problems, missing variables etc. (see, e.g., Berger et al., 2005; Casey \& O’Toole, 2014; García \& Gómez, 2018 etc.). We leave the details of econometric analysis for future research. 


\section{Conclusions}

In this paper we analyze a firm choice between crowdfunding and bank financing. Crowdfunding is an area of great interest among theorists and practitioners. Bank financing remains a very important source of financing for businesses. We analyze a model where the choice of financing is affected by moral hazard problem regarding the choice of production scale that favors bank financing, and by the uncertainty about consumer valuation of the product that favors crowdfunding. The model predicts that if the market limitations are soft, crowdfunding may not be feasible due to moral hazard problems related to production scale choice during spot sales. Second when crowdfunding is feasible the trade-off between bank financing and crowdfunding depends on interplay of bankruptcy cost, investment size, the type of crowdfunding, the type of signal received etc. For example we find that mixed financing may be optimal when crowdfunding market is quite limited but at the same time the investment size is relatively large. In this case pure crowdfunding may not deliver sufficient funds to cover investment costs while pure bank financing may imply large investment losses when demand is low. We also find that firms would usually prefer short campaigns to long campaigns since they have more chances to be feasible and overcome the moral hazard problem related to production scale choice. Also we find that for a given amount of investment a firm of higher quality/or larger market size will look for a bank loan. The model generates empirical predictions most of that have not been tested sofar.

\section{Appendix. Proof of Proposition 5}

First consider the firm production decision. The firm reaches this stage when the crowdfunding campaign is completed and the decision was made to not stop the project. Also at this stage the demand is known. Let $C$ be the amount of funds raised by crowdfunding: $C=p_{c} q_{c}$. Production stage can only be reached in a "good" scenario, i.e., one with a positive demand. The entrepreneur chooses $q_{s}$ to maximize $q_{s}\left(a-q_{s}-q_{c}\right)+$ $\Pi_{1}$ where $\Pi_{1}=\max \{0, C+D-I-F-K-B\}$. Two cases are possible. 1. $a>q_{c}$. Then optimal $q_{s}^{*}=\frac{a-q_{c}}{2}$ and the firm profit equals:

$\frac{\left(a-q_{c}\right)^{2}}{4}+\Pi_{1}$

2. $a \leq q_{c}$. Optimal $q_{s}=0$ and the firm profit equals $\Pi_{1}$.

Now consider firm decision after the campaign is completed and the signal is received. The entrepreneur has 2 options: project termination or continuation. If the firm learned that $a=0$, the project will be terminated because the entrepreneur's profit cannot be positive. Consider a good case with positive demand. Two scenarios are possible.

1. $C+D>I$. Then if the firm is liquidated, the entrepreneur gets $\Pi_{1}$. If the firm continues, then the entrepreneur's profit is given by (A.1). If $a>$ $q_{c}$, the entrepreneur will decide to continue.

2. $C+D<I$. Then the firm cannot continue. So the project is terminated and the entrepreneur's profit is 0 . In fact in this case, no one will invest in crowdfunding and the campaign fails.

Initially the firm sets the price $p_{c}$ to maximize the entrepreneur's expected profit $\Pi$. Two scenarios are possible depending on expected decision at production stage. If the entrepreneur anicipates $q_{s}>0$ then initially he maximizes $\Pi=0.5\left(\frac{\left(a-q_{c}\right)^{2}}{4}+p_{c} q_{c}+D-\right.$ $F-I)-K-B$ subject to $p_{c} q_{c}+D \geq I$, no-arbitrage condition

$p_{s}=a-q_{s}-q_{c}=\frac{a-q_{c}}{2} \geq p_{c}$,

$a \geq q_{c}$ and $p_{s}<a$. The last condition can be rewritten as $0 \leq a+q_{c}$ that holds. If the entrepreneur expects $q_{s}=0$, then he maximizes $\Pi=0.5\left(p_{c} q_{c}+D-I-\right.$ $F)-K-B$ subject to $p_{c} q_{c}+D \geq I+B+K, a<q_{c}$ and $p_{s}<a$.

Two cases are possible. 1. $p_{c} \geq a-\bar{q}$. This implies $a-p_{c} \leq \bar{q}$ and $q_{c}=a-p_{c}$. Then $p_{s}=a-q_{s}-q_{c}=$ $\frac{a-q_{c}}{2}=\frac{p_{c}}{2}$ and the no-arbitrage condition (A.2) can be written as $\frac{p_{c}}{2} \geq p_{c}$ that does not hold because in this case the firm will not create any profit. 
2.

$p_{c}<a-\bar{q}$

(note that this only works if $a>\bar{q}$ ). This implies $a-$ $p_{c}>\bar{q}$ and $q_{c}=\bar{q}$. Then $p_{s}=\frac{a-\bar{q}}{2}$ and the noarbitrage condition (A.2) can be written as

$\frac{a-\bar{q}}{2} \geq p_{c}$

Then according to (A.1) the firm expects $q_{s}>0$ and hence it maximizes $0.5\left(\frac{\left(a-q_{c}\right)^{2}}{4}+p_{c} q_{c}+D-F-I\right)-K-B=$ $0.5\left(\frac{(a-\bar{q})^{2}}{4}+p_{c} \bar{q}-I\right)$ subject to (A.4) and $p_{c} \bar{q} \geq I$. The solution is

$p_{c}^{\prime}=\frac{a-\bar{q}}{2}$

The firm sets $p_{c}=\frac{a-\bar{q}}{2}$. When the signal is good, $a-p_{c}>\bar{q}$ so $q_{c}=\bar{q}$ and the firm continues. $p_{s}=$ $a-q_{s}-q_{c}=\frac{a-\bar{q}}{2}=p_{c}, q_{s}=\frac{a-\bar{q}}{2} . D=I+2 K+$ $2 B-p_{c} \bar{q}=I+K+B-\frac{(a-\bar{q}) \bar{q}}{2}$. The firm's expected profit equals:

$$
\begin{aligned}
& 0.5\left(\frac{\left(a-q_{c}\right)^{2}}{4}+p_{c} q_{c}+D-F-I\right)-K-B \\
= & \frac{(a-\bar{q})^{2}}{8}+\frac{(a-\bar{q}) \bar{q}}{4}-0.5 I-K-B
\end{aligned}
$$

Acknowledgements I am grateful to Julie Ann Elston and two anonymous referees for their invaluable comments and suggestions. Also many thanks to Vincent Crawford, Gary Dushnitsky, Geoffrey Hodgson, Todd Kaplan, Peter Klein, Claire Leitch, Victor Miglo, Simon C Parker, Deborah Trask, and the seminar participants at Ulster University, University of Waikato and University of Twente for their helpful comments and editing assistance.

Open Access This article is licensed under a Creative Commons Attribution 4.0 International License, which permits use, sharing, adaptation, distribution and reproduction in any medium or format, as long as you give appropriate credit to the original author(s) and the source, provide a link to the Creative Commons licence, and indicate if changes were made. The images or other third party material in this article are included in the article's Creative Commons licence, unless indicated otherwise in a credit line to the material. If material is not included in the article's Creative Commons licence and your intended use is not permitted by statutory regulation or exceeds the permitted use, you will need to obtain permission directly from the copyright holder. To view a copy of this licence, visit http:// creativecommons.org/licenses/by/4.0/.

\section{References}

Ahlers, G., Cumming, D., Günther, C., \& Schweizer, D. (2015). Signaling in equity crowdfunding. Entrepreneurship Theory and Practice, 39(4), 955-980. https://doi.org/10.1111/ etap. 12157.

Ahlstrom, D., Cumming, D., \& Vismara, S. (2018). New methods of entrepreneurial firm financing: fintech, crowdfunding and corporate governance implications. Corporate Governance - An International Review, 26(5), 310-313. https://doi.org/10.1111/corg.12258.

Ang, J. (1992). On the theory of finance for privately held firms. Journal of Small Business Finance, 1, 185-203. https:// digitalcommons.pepperdine.edu/jef/vol1/iss $3 / 1$.

Ang, J., Cole, R., \& Lawson, J. (2010). The role of owner in capital structure decisions: An analysis of single-owner corporations. Journal of Entrepreneurial Finance, 14, 1-36. https://digitalcommons.pepperdine.edu/ cgi/viewcontent.cgi?article $=1015 \&$ context $=$ jef.

Antweiler, W., \& Frank, M. Z. (2006). Do U.S. stock markets typically overreact to corporate news stories?, working paper, UBC and University of Minnesota. https://doi.org/ 10.2139/ssrn.878091.

Arcot, S. (2014). Participating convertible preferred stock in venture capital exits. Journal of Business Venturing, 29(1), 72-87. https://doi.org/10.1016/j.jbusvent.2013.06.001.

Arkrot, W., Unger, A., \& Åhlström, E. (2017). Crowdfunding from a Marketing Perspective. Thesis. http://www. diva-portal.org/smash/get/diva2:1106397/FULLTEXT01. pdf.

Arnold, L., \& Riley, J. (2009). On the possibility of credit rationing in the stiglitz-weiss model. American Economics Review, 99, 2012-2021. https://www.jstor.org/ stable/25592545.

Azizaj, E. (2020). FinTech marketplace lending, default risk, and the business cycle. Available at SSRN: https://ssrn.com/ abstract=3738793 or https://doi.org/10.2139/ssrn.3738793.

Babich, V., Marinesi, S., \& Tsoukalas, G. (2019). Does crowdfunding benefit entrepreneurs and venture capital investors? Manufacturing \& Service Operations Management. Forthcoming. Available at SSRN: https://ssrn.com/ abstract $=2971685$ or https://doi.org/10.2139/ssrn.2971685.

Beck, T., \& Demirguc-Kunt, A. (2006). Small and mediumsize enterprises: access to finance as a growth constraint. Journal of Banking \& Finance, 30(11), 2931-2943. https://doi.org/10.1016/j.jbankfin.2006.05.009.

Beier, M., Früh, S., \& Jäger, C. (2019). Reward-based crowdfunding as a marketing tool for established SMEs: a multi case study* swiss institute for entrepreneurship University of Applied Sciences HTW Chur, Switzerland. https://doi.org/10.2139/ssrn.3338084.

Belavina, E., Marinesi, S., \& Tsoukalas, G. (2020). Rethinking crowdfunding platform design: mechanisms to deter misconduct and improve efficiency. Management Science. Forthcoming. Available at SSRN: https://ssrn.com/ abstract=3093437 or https://doi.org/10.2139/ssrn.3093437.

Belleflamme, P., Lambert, T., \& Schwienbacher, A. (2014). Crowdfunding: Tapping the right crowd. Journal of Business Venturing, 29(5), 585-609. https://doi.org/10.1016/j. 
jbusvent.2013.07.003.

Berger, A., \& Udell, G. (1998). The economics of small business finance: The roles of private equity and debt markets in the financial growth cycle. Journal of Banking and Finance, 22, 613-673. http://www.sciencedirect.com/science/article/ pii/S0378-4266(98)00038-7.

Berger, A., Miller, N., Petersen, M., Rajan, R., \& Stein, J. (2005). Does function follow organizational form? Evidence from the lending practices of large and small banks. Journal of Financial Economics, 76(2), 237-269.

Bernardino, S., \& Santos, J. F. (2020). Crowdfunding: an exploratory study on knowledge, benefits and barriers perceived by young potential entrepreneurs. Journal of Risk and Financial Management, 13(4), 81. https://doi.org/10. 3390/jrfm13040081.

Bester, H. (1987). The role of collateral in credit markets with imperfect information. European Economic Review, 31(4), 887-899. http://www.sciencedirect.com/science/article/pii/ 0014-2921(87)90005-5.

Bhattacharya, S., \& Thakor, A. (1993). Contemporary banking theory. Journal of Financial Intermediation, 3(1), 2-50. https://doi.org/10.1006/jfin.1993.1001.

Blaseg, D., \& Koetter, M. (2016). Crowdfunding and bank stress. In Banking beyond banks and money (pp. 1754). Cham: Springer. https://www.springer.com/gp/book/ 9783319424460 .

Bolton, P., \& Scharfstein, D. A. (1990). Theory of predation based on agency problems in financial contracting. American Economic Review, 80(1), 93-106. https://EconPapers. repec.org/RePEc:aea:aecrev:v:80:y:1990:i:1:p:93-106.

Brander, J., \& Lewis, T. (1986). Oligopoly and financial structure: the limited liability effect, (Vol. 76. https:// EconPapers.repec.org/RePEc:aea:aecrev:v:76:y:1986:i:5:p: 956-70.

Brav, O. (2009). Access to capital, capital structure, and the funding of the firm, (Vol. 64. https://doi.org/10.1111/j. 1540-6261.2008.01434.x.

British Business Bank (2019/20). Small Business Finance report. https://www.british-business-bank.co.uk/wp-cont ent/uploads/2020/02/Small-Business-Finance-Markets-201 9-20-report-FINAL.pdf.

Casey, E., \& O'Toole, C. M. (2014). Bank lending constraints, trade credit and alternative financing during the financial crisis: Evidence from European SMEs. Journal of Corporate Finance, 27, 173-193.

Chakraborty, S., \& Swinney, R. (2019). Signalling to the crowd: private quality information and rewards-based crowdfunding. Manufacturing and Service Operations Management Forthcoming. Available online: https://doi.org/10.2139/ ssrn.2885457.

Chemla, G., \& Tinn, K. (2019). Learning through crowdfunding. Management Science, 66(5), 1783-2290. https://doi. org/10.2139/ssrn.2796435.

Chen, R. R., Gal-Or, E., \& Roma, P. (2018). Reward-based crowdfunding campaigns: Informational value and access to venture capital. Information Systems Research, 29, 679697. https://doi.org/10.1287/isre.2018.0777.

Chod, J., \& Lyandres, E. (2019). A theory of ICOs: diversification, agency, and information asymmetry. Available at SSRN: https://ssrn.com/abstract=3159528.
Chod, J., \& Lyandres, E. (2021). A theory of ICOs: diversification, agency, and information asymmetry. Management Science, 67(10), 5969-5989. https://doi.org/10.1287/mnsc. 2020.3754.

Cole, R. (2010). Bank credit, trade credit or no credit? Evidence from the Surveys of Small Business Finances, U.S, Small Business Administration Research Study No. 365. https:// ideas.repec.org/p/pra/mprapa/24689.html.

Cole, R. (2013). What do we know about the capital structure of privately held firms? Evidence from the surveys of small business finances. Financial Management (Winter), 777-813. https://doi.org/10.1111/fima.12015.

Cole, R., Cumming, D., \& Taylor, J. (2019). Does FinTech compete with or complement bank finance? Available at SSRN: https://ssrn.com/abstract=3302975 or https://doi.org/10. 2139/ssrn.3302975.

Cuñat, V., \& Garcia-Appendini, E. (2012). Trade credit and its role in entrepreneurial finance. In D. Cumming (Ed.) The Oxford handbook of entrepreneurial finance (pp. 526-557). London: Oxford University Press. https://doi.org/10.1093/ oxfordhb/9780195391244.013.0018.

Cumming, D., Leboeuf, G., \& Schwienbacher, A. (2019). Crowdfunding models: keep-it-all versus all or nothing, financial management, forthcoming. https://doi.org/10. 1111/fima.12262.

De Bettignies, J.-E., \& Brander, J. (2007). Financing entrepreneurship: bank finance vs. venture capital. Journal of Business Venturing, 22(6), 808-832. https://doi.org/10. 1016/j.jbusvent.2006.07.005.

De Buysere, K., Gajda, K., Oliver, R., \& Marom, D. (2012). A framework for European crowdfunding. European Crowdfunding Network (ECN). Available online: www.europecrowdfunding.org/european_crowdfunding framework (accessed on 15 February 2020).

Diamond, D. (1984). Financial intermediation and delegated monitoring. The Review of Economic Studies, 51(3), 393414. https://doi.org/10.2307/2297430.

Durkin, M., Laffey, D., Gandy, A., Cummins, D., \& Fearon, C. (2016). The SME-bank relationship: exploring the impact of crowdfunding at start-up. A research study by Ulster University Business School, Kent Business School and the London Institute of Banking and Finance. https://www.ulster.ac.uk/__data/assets/pdf_ file/0009/168417/crowdfunding.pdf.

Eckbo, B. E. (1986). Valuation effects of corporate debt offerings. Journal of Financial Economics, 15, 119-151. https://doi.org/10.1016/0304-405X(86)90052-8.

Eddleston, K. A., Ladge, J. J., Mitteness, C., \& Balachandra, L. (2016). Do you see what I see? Signaling effects of gender and firm characteristics on financing entrepreneurial ventures. Entrepreneurship Theory and Practice, 40(3), 489-514. https://doi.org/10.1111/etap.12117.

Estrin, S., Gozman, D., \& Khavul, S. (2018). The evolution and adoption of equity crowdfunding: entrepreneur and investor entry into a new market. Small Business Economics, 51(2), 425-439. https://doi.org/10.1007/s11187-018-0009-5.

Fairchild, R., Liu, W., \& Yao, Y. (2017). An entrepreneur's choice of crowd-funding or venture capital financing: the effect of entrepreneurial overconfidence and cfinvestors' passion. University of Bath working paper. 
https://researchportal.bath.ac.uk/en/publications/an-entrepr eneurs-choice-of-venture-capitalist-or-angel-financing-.

Fama, E., \& French, K. R. (2002). Testing trade-off and pecking order predictions about dividends and debt. Review of Financial Studies, 15, 1-33. https://www.jstor.org/stable/ 2696797.

Fenwick, M., McCahery, J., \& Vermeulen, E. (2017). Fintech and the financing of entrepreneurs: from crowdfunding to marketplace lending. ECGI Working Paper Series in Law. https://doi.org/10.2139/ssrn.2967891.

Frank, M. Z., \& Goyal, V. K. (2009). Capital structure decisions: which factors are reliably important? Financial Management, 38(1), 1-37. https://doi.org/10.1111/j.1755-053X. 2009.01026.x

Gabison, G. A. (2015). Understanding crowdfunding and its regulations EUR 26992. Luxembourg (Luxembourg): Publications Office of the European Union; 2014. JRC92482. https://doi.org/10.2791/562757.

García, M., \& Gómez, P. (2018). Credit constraints, firm investment and growth: evidence from survey data, working paper.

Gonçalves, V., Martins, F., \& Brandão, E. (2014). The determinants of credit default on start-up firms. Econometric Modelling using Financial Capital, Human Capital and Industry Dynamics Variables. FEP working paper.

Hotchkiss, E. S., John, K., Mooradian, R. M., \& Thorburn, K.S. (2008). Bankruptcy and the resolution of financial distress. In E. Eckbo (Ed.) Handbook of empirical corporate finance, Vol. 2. Chapter 14. http://mba.tuck.dartmouth.edu/pages/ faculty/karin.thorburn/publications/ch14-n53090.pdf.

Hrůzová, L., \& Vaceková, G. (2018). Profitable nonprofits? reward-based crowdfunding in the Czech Republic. NISPAcee Journal of Public Administration and Policy, 10(2), 203-227. https://doi.org/10.1515/nispa-2017-0019.

Hui, J., Gerber, E., \& Gergle, D. (2014). Understanding and leveraging social networks for crowdfunding: implications for support tools. In Extended abstracts on human factors in computing systems (pp. 2083-2088). https://doi.org/10.1145/2559206.2581289.

Jaffee, D., \& Russell, T. (1976). Imperfect information, uncertainty, and credit rationing. The Quarterly Journal of Economics, 90(4), 651-666. https://doi.org/10.2307/1885327.

Kgoroeadira, R., Burke, A., \& van Stel, A. (2019). Small business online loan crowdfunding: who gets funded and what determines the rate of interest? Small Business Economics, 52(1), 67-87. https://doi.org/10.1007_s11187-017-9986-z.

Kim, J.-H., Newberry, P., \& Qiu, C. (2018). The role of information signals in determining crowdfunding outcomes. https://www.tse-fr.eu/sites/default/files/TSE/documents/ ChaireJJL/Digital-Economics-Conference/Conference/ kim_jin-hyuk.pdf.

Kleinert, S., Volkmann, C., \& Grünhagen, M. (2020). Thirdparty signals in equity crowdfunding: the role of prior financing, (Vol. 54. https://doi.org/10.1007/s11187-0180125-2

Kohler, M., Britton, E., \& Yates, A. (2000). Trade credit and the monetary transmission mechanism. Working paper No. 115, Bank of England. https://doi.org/10.2139/ssrn.234693.

Landier, A. (2002). Start-up financing: from banks to venture capital. https://www.researchgate.net/publication/
247639116_Start-up_Financing_From_Banks_to_Venture Capital.

Lehmann, B. (2003). Is it worth the while? The relevance of qualitative information in credit rating. Working paper University of Konstanz apresentado no encontro EFMA 2003 em Helsínquia.

Leland, H. E. (1994). Corporate debt value, bond covenants and optimal capital structure. Journal of Finance, 49, 1213 1252. https://doi.org/10.2307/2329184.

Leland, H. E., \& Pyle, D. H. (1977). Information asymmetries, financial structure, and financial intermediation. Journal of Finance, 32, 371-378. https://ssrn.com/abstract=1506388.

Leland, H. E., \& Toft, K. B. (1996). The optimal capital structure, endogenous bankruptcy and the term structure of credit spreads. Journal of Finance, 51, 987-1019. https://doi.org/10.1111/j.1540-6261.1996.tb02714.x.

Lenz, R. (2016). Peer-to-peer lending - opportunities and risks, (Vol. 7. https://doi.org/10.1017/S1867299X00010126.

Liberti, J. M., \& Petersen, M. A. (2019). Information: hard and soft. The Review of Corporate Finance Studies, 8(1), 1-41. https://doi.org/10.1093/rcfs/cfy009.

Li, L., \& Wang, Z. (2019). How does capital structure change product-market competitiveness? Evidence from Chinese firms. PLoS One, 14(2), 1-14. https://doi.org/10.1371/ journal.pone.0210618.

Lukkarinen, A., Teich, J. E., Wallenius, H., \& Wallenius, J. (2016). Success drivers of online equity crowdfunding campaigns. Decision Support Systems, 87, 26-38. https:// iranarze.ir/wp-content/uploads/2016/12/E3228.pdf.

Miglo, A., \& Miglo, V. (2019). Market imperfections and crowdfunding. Small Business Economics, 53(1), 51-79. https://doi.org/10.1007/s11187-018-0037-1.

Miglo, A. (2020a). Crowdfunding in a competitive environment. Journal of Risk and Financial Management, Special Issue on Crowdfunding. Ed. D. Cumming and S. Johan. 13(3), 39. https://doi.org/10.3390/jrfm13030039.

Miglo, A. (2020b). Crowdfunding under market feedback, asymmetric information and overconfident entrepreneur. Entrepreneurship Research Journal Forthcoming. Available online: https://mpra.ub.unimuenchen.de/89015/1/ MPRA_paper_89015.pdf (accessed on 22 February 2020).

Mochkabadi, K., \& Volkmann, C. (2020). Equity crowdfunding: a systematic review of the literature. Small Business Economics, 54, 75-118. https://doi.org/10.1007/s11187-0180081-X.

Modigliani, F., \& Miller, M. (1958). The cost of capital, corporation finance and the theory of investment. American Economic Review, 48(3), 261-297. https://www.jstor.org/ stable/1809766.

Mollick, E. (2014). The dynamics of crowdfunding: an exploratory study. Journal of Business Venturing, 29(1), 1-16. https://doi.org/10.1016/j.jbusvent.2013.06.005.

Moritz, A., \& Block, J. (2014). Crowdfunding: a literature review and research directions. Available at SSRN: http:// ssrn.com/abstract=2554444 or https://doi.org/10.2139/ssrn. 2554444.

Paakkarinen, P. (2016). Success factors in reward based and equity based crowdfunding in Finland master's thesis. https://core.ac.uk/download/pdf/80719599.pdf. 
Parker, S. (2002). Do banks ration credit to new enterprises? And should governments intervene? Scottish Journal of Political Economy, 49(2), 162-195. https://doi.org/10.1111/ 1467-9485.00227.

Platt, K. (2020). Corporate bonds and product market competition. The Journal of Financial Research, 43(3), 615-647. https://doi.org/10.1111/jfir.12220.

PwC (2008). Cost of borrowing A practical guide to capitalisation of borrowing costs November 2008. https://www.pwc. com/gx/en/ifrs-reporting/pdf/guide_capitalisation_brwg_ costs.pdf.

Rajan, R., \& Zingales, L. (1995). What do we know about capital structure? some evidence from international data. The Journal of Finance, 50(5), 1421-1460. https://doi.org/ 10.1111/j.1540-6261.1995.tb05184.x.

Robb, A. M., \& Robinson, D. T. (2012). The capital structure decisions of new firms. The Review of Financial Studies, 1(1), 1-27. https://doi.org/10.1093/rfs/hhs072.

Roma, P., Petruzzelli, A. M., \& Perrone, G. (2017). From the crowd to the market: The role of rewardbased crowdfunding performance in attracting professional investors. Research Policy, 46(9), 1606-1628. https://doi.org/10.1016/j.respol.2017.07.012.

Ross, S. A. (1977). The determination of financial structure: The incentive signaling approach. Bell Journal of Economics, 8, 23-40. https://doi.org/10.2307/3003485.

Salahaldin, L., Angerer, M., Kraus, S., \& Trabelsi, D. (2019). A duration-based model of crowdfunding project choice. Finance Research Letters, 29, 404-410. https://doi.org/10.1016/j.frl.2018.11.005.

Schwienbacher, A. (2018). Entrepreneurial risk-taking in crowdfunding campaigns. Small Business Economics, 51(4), 843859. https://doi.org/10.1007/s11187-017-9965-4.

Senbet, L. W., \& Seward, J. K. (1995). Financial distress, bankruptcy and reorganization. In R. A. Jarrow, et al. (Eds.) Handbooks in operations research and management science, (Vol. 9 pp. 921-961). Elsevier Science. https://ssrn. com/abstract $=2268540$.

Senbet, L. W., \& Wang, T. Y. (2012). Corporate financial distress and bankruptcy: a survey. Foundations and Trendsin Finance, 5(4), 243-335. https://doi.org/10.1561/050000 0009.

Stiglitz, J., \& Weiss, A. (1981). Credit rationing in markets with imperfect information. American Economic Review, 73, 93-409. https://www.jstor.org/stable/1802787.

Strausz, R. (2017). Crowdfunding, demand uncertainty, and moral hazard - a mechanism design approach. American Economic Review, 107(6), 1430-76. https://doi.org/10. 1257/aer.20151700.

Su, X., \& Zhang, L. (2014). A re-examination of credit rationing in the Stiglitz and weiss model. Available at SSRN: http:// ssrn. .com/abstract $=1703428$.

Tamburro, A. (2018). Far from madding crowd: Crowdfunding a small business reorganization. EMORY Bankruptcy Developments Journal, 34, 521-559. https://scholarlycommons. law.emory.edu/ebdj/vol34/iss2/8/.

Titman, S., \& Wessels, R. (1988). The determinants of capital structure choice. Journal of Finance, 43, 1-21. https://doi. org/10.1111/j.1540-6261.1988.tb02585.x.

Tuo, G., Feng, Y., \& Sarpong, S. (2019). Wang, w, The second round resource acquisition of entrepreneurial crowdfunded ventures: the relevance of campaign and project implementation performance outcomes. Entrepreneurship Research Journal, forthcoming. https://doi.org/10.1515/erj-2018-0123.

Vulkan, N., Åstebro, T., \& Sierra, M. (2016). Equity crowdfunding: a new phenomena. Journal of Business Venturing Insights, 5, 37-49. https://doi.org/10.1016/j.jbvi.2016. 02.001 .

Yazdanfar, D., \& Öhman, P. (2017). Substitute or complement? The use of trade credit as a financing source among SMEs. Management Research Review, 40(1), 1027. https://doi.org/10.1108/MRR-06-2015-0153.

Watson, H. (1984). Credit markets and borrower effort. Southern Economic Journal, 50, 802-813. https://doi.org/10. 2307/1057994.

Weston, F. J. (1977). Some economic fundamentals for an analysis of bankruptcy. Law and Contemporary Problems, 41, 47-65. https://scholarship.law.duke.edu/lcp/vol41/iss4/4

Williams, J. (1995). Financial and industrial structure with agency. The Review of Financial Studies, 8, 431-475. https://ideas.repec.org/a/oup/rfinst/v8y1995i2p431-74. html.

Winton, A., \& Yerramilli, V. (2008). Entrepreneurial finance: Banks versus venture capital. Journal of Financial Economics, 88, 51-79. https://doi.org/10.1016/j.jfineco.2007. 05.004 .

$\mathrm{Xu}, \mathrm{T}$. (2018). Learning from the crowd: the feedback value of crowdfunding. University of British Columbia working paper. https://privpapers.ssrn.com/sol3/papers.cfm? abstract_id $=2637699$.

Xu, F., Guo, X., Xiao, G., \& Zhang, F. (2020). Crowdfunding vs. bank financing: effects of market uncertainty and word-of-mouth communication. Bank financing: effects of market uncertainty and word-of-mouth communication. working paper, available at SSRN: https://ssrn.com/ abstract $=3707839$.

Publisher's note Springer Nature remains neutral with regard to jurisdictional claims in published maps and institutional affiliations. 